Article

\title{
Supercritical Fluid Extraction of Fucoxanthin from the Diatom Phaeodactylum tricornutum and Biogas Production through Anaerobic Digestion
}

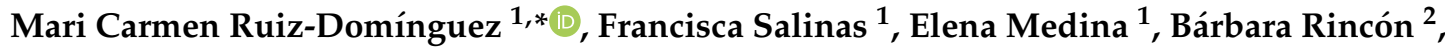 \\ Marí Ángeles Martín ${ }^{3,4} \odot$, Marí Carmen Gutiérrez ${ }^{3,4}$ and Pedro Cerezal-Mezquita ${ }^{1, *}$
}

check for

updates

Citation: Ruiz-Domínguez, M.C.;

Salinas, F.; Medina, E.; Rincón, B.;

Martín, M.Á.; Gutiérrez, M.C.;

Cerezal-Mezquita, P. Supercritical

Fluid Extraction of Fucoxanthin from

the Diatom Phaeodactylum tricornutum

and Biogas Production through

Anaerobic Digestion. Mar. Drugs

2022, 20, 127. https://doi.org/

$10.3390 / \mathrm{md} 20020127$

Academic Editor: Igor Jerković

Received: 13 January 2022

Accepted: 4 February 2022

Published: 7 February 2022

Publisher's Note: MDPI stays neutral with regard to jurisdictional claims in published maps and institutional affiliations.

Copyright: (C) 2022 by the authors. Licensee MDPI, Basel, Switzerland. This article is an open access article distributed under the terms and conditions of the Creative Commons Attribution (CC BY) license (https:// creativecommons.org/licenses/by/ $4.0 /)$.
1 Laboratorio de Microencapsulación de Compuestos Bioactivos (LAMICBA), Departamento de Ciencias de los Alimentos y Nutrición, Facultad de Ciencias de la Salud, Universidad de Antofagasta, Antofagasta 1240000, Chile; francisca.salinas@uantof.cl (F.S.); elena.medina.perez@ua.cl (E.M.)

2 Instituto de la Grasa, Consejo Superior de Investigaciones Científicas (CSIC), Campus Universidad Pablo de Olavide, Edificio 46. Ctra. de Utrera km. 1, 41013 Seville, Spain; brlloren@cica.es

3 Departamento de Química Inorgánica e Ingeniería Química, Universidad de Córdoba, Campus Universitario de Rabanales, 14071 Córdoba, Spain; iq2masam@uco.es (M.Á.M.); a12gumam@uco.es (M.C.G.)

4 Instituto de Química Fina y Nanotecnología (IUNAN), Universidad de Córdoba, Campus de Excelencia Internacional Agroalimentario CeiA3, Edificio Marie Curie (C-3), Ctra. N-IV, km 396, 14071 Córdoba, Spain

* Correspondence: maria.ruiz@uantof.cl (M.C.R.-D.); pedro.cerezal@uantof.cl (P.C.-M.); Tel.: +56-552-633-660 (M.C.R.-D.)

\begin{abstract}
Phaeodactylum tricornutum is the marine diatom best known for high-value compounds that are useful in aquaculture and food area. In this study, fucoxanthin was first extracted from the diatom using supercritical fluid extraction (SFE) and then using the extracted diatom-like substrate to produce bioenergy through anaerobic digestion (AD) processes. Factors such as temperature $\left(30{ }^{\circ} \mathrm{C}\right.$ and $50{ }^{\circ} \mathrm{C}$ ), pressure $(20,30$, and $40 \mathrm{MPa}$ ), and ethanol (co-solvent concentration from $10 \%$ to $50 \% \mathrm{v} / \mathrm{v}$ ) were optimized for improving the yield, purity, and recovery of fucoxanthin extracted using SFE. The highest yield $(24.41 \% \mathrm{w} / \mathrm{w})$ was obtained at $30 \mathrm{MPa}, 30{ }^{\circ} \mathrm{C}$, and $30 \%$ ethanol but the highest fucoxanthin purity and recovery $(85.03 \mathrm{mg} / \mathrm{g}$ extract and $66.60 \% \mathrm{w} / \mathrm{w}$, respectively) were obtained at $30 \mathrm{MPa}, 30^{\circ} \mathrm{C}$, and $40 \%$ ethanol. Furthermore, ethanol as a factor had the most significant effect on the overall process of SFE. Subsequently, P.tricornutum biomass and SFE-extracted diatom were used as substrates for biogas production through AD. The effect of fucoxanthin was studied on the yield of $\mathrm{AD}$, which resulted in $77.15 \pm 3.85 \mathrm{LSTP} \mathrm{CH}_{4} / \mathrm{kg}$ volatile solids (VS) and $56.66 \pm 1.90 \mathrm{LSTP} \mathrm{CH}_{4} / \mathrm{kg}$ VS for the whole diatom and the extracted P.tricornutum, respectively. Therefore, P.tricornutuman can be considered a potential source of fucoxanthin and methane and both productions will contribute to the sustainability of the algae-biorefinery processes.
\end{abstract}

Keywords: Phaeodactylum tricornutum; supercritical fluid extraction; co-solvent; fucoxanthin; anaerobic digestion; algae biorefinery

\section{Introduction}

Diatoms are unicellular photosynthetic eukaryotes that are commonly found in marine ecosystems and moist terrestrial habitats. They contribute to about $20-25 \%$ of global carbon dioxide fixation through photosynthesis and play an important role in the global silicon cycle [1,2]. In addition, they are a part of the base of marine trophic networks worldwide and contribute to at least $20 \%$ of annual primary productivity, which is equivalent to tropical forests [3,4]. Among the organic molecules produced by diatoms, fatty acids or 
carotenoids are essential in the nutrition of benthic and pelagic animals [5]. Recently, novel and green applications have been discovered from intracellular molecules present in diatoms such as total lipids for biodiesel and amino acids for cosmetic, antibiotic, and antiproliferative agents or bioremediation uses [6-8].

Phaeodactylum tricornutum is a well-recognized marine pennate diatom. It is a unicellular brown alga and the most-studied model diatom due to its nutrition-rich biochemical composition. It is widely used as feed for larvae because it produces compounds essential for the nutrition of other animals, such as proteins, carbohydrates, lipids, polyunsaturated fatty acids, and carotenoids (among them fucoxanthin) [5,9,10]. Moreover, it is characterized by fast growth and simple culturing requirements. Fucoxanthin is a yellowish carotenoid (xanthophyll) with an allenic carbon chain, an acyclic keto group, and a hydroxyl group at one of the $\beta$-ionone rings esterified with acetic acid [11,12]. This bioactive compound exhibits various biological properties beneficial to human health such as antiobesity, antidiabetic, anticancer, anti-allergic, and anti-inflammatory properties $[13,14]$. Furthermore, fucoxanthin content is much higher in diatoms than in seaweed (ranging from $0.22 \%$ to $2.17 \%$ of dry weight) [15].

The need for investigating novel alternative bioactive compounds extracted from natural biomass has increased. Green extraction techniques is a favored approach as it not only improves the extraction of high-value molecules but can also extract biomolecules without changing their conformation or bioactive properties and uses green solvents, thus contributing to environmental sustainability $[16,17]$. Several green extraction techniques exist, such as microwave-assisted extraction (MAE), ultrasound-assisted extraction (UAE), pulsed electric fields (PEF), pressurized liquid extraction (PLE), and supercritical fluids extraction (SFE) [16,18]. SFE has operational advantages over conventional extraction methods. SFE uses supercritical solvents such as carbon dioxide $\left(\mathrm{CO}_{2}\right)$ due to their safety, low cost, and different polarity modifiers as co-solvent. Variables such as pressure, temperature, and solvent flow can be modulated in SFE to obtain different physicochemical properties of supercritical solvents such as density, diffusivity, viscosity, and dielectric constant [18,19].

"Algae-biorefinery" is a new concept describing the sustainable production of highvalue molecules as co-products from algae biofuels as well as biofuels by the integration of bioprocessing and effective technologies in a cost-effective manner that minimizes environmental impact $[20,21]$. Biofuel is the result of energy conversion from natural biomass in biological processes that include anaerobic digestion (AD), alcoholic fermentation, photobiological hydrogen production, transesterification, and in situ transesterification [20,22]. Particularly, AD is focused on the production of biogas, primarily methane and carbon dioxide, with traces of other gases such as hydrogen sulfide by the conversion of organic material [23]. This process takes place in four sequential stages: hydrolysis, acidogenesis, acetogenesis, and methanogenesis [24,25].

Lipids or other compounds in value-added extraction can increase the biodegradability of microalgae; however, it depends on the solvent used in the extraction process. After extraction, methane production can be inhibited through AD [26]. Lage et al. [27] reported that the use of extracted microalgae increased the potential of methane production when the rest of the solvents were evaporated compared with the system where extracted solventimpregnated microalgae were used. This situation could be explained by the negative effect of organic solvents [27]. Some organic solvents exhibit an inhibitory effect as chloroform, which disrupts the microbial cell membrane, thus compromising cell viability [28], or hexane and isopropanol [27]. Conversely, the results of the Cord-Ruwisch [29] study showed that ethanol and lactic acid were the intermediate products that could be potentially produced during the acid stage of anaerobic fermentation.

Evaporation of organic solvents in a previous stage of anaerobic fermentation is an alternative to improve the results of $\mathrm{AD}[26,27]$. However, evaporation is an energydemanding process that should be evaluated to determine the costs and the effect on the overall energy balance of the digestion process. The use of green technologies such as SFE 
avoids all the problems associated with the use of inhibitory organic solvents by facilitating the valorization of extracted microalgae through AD.

In this study, we performed supercritical carbon dioxide $\left(\mathrm{SCO}_{2}\right)$ extraction of fucoxanthin from the diatom P. tricornutum and $\mathrm{AD}$ of the extracted microalga under microalgae biorefinery frame. We also studied the effects of factors such as temperature, pressure, and co-solvent concentration on variables such as the total extraction yield, fucoxanthin purity, and recovery. Finally, the biochemical composition of P. tricornutum and methane yields before and after the SFE process were studied to determine how the use of a green extraction system affects methane production.

\section{Results and Discussion}

\subsection{Effects of Pressure and Temperature on the Yield of Fucoxanthin from P. tricornutum}

Total extraction yields for each operating conditions (temperature of $30^{\circ} \mathrm{C}$ and $50{ }^{\circ} \mathrm{C}$ and pressure of 20,30, and $40 \mathrm{MPa}$ ) are summarized in Figure 1.

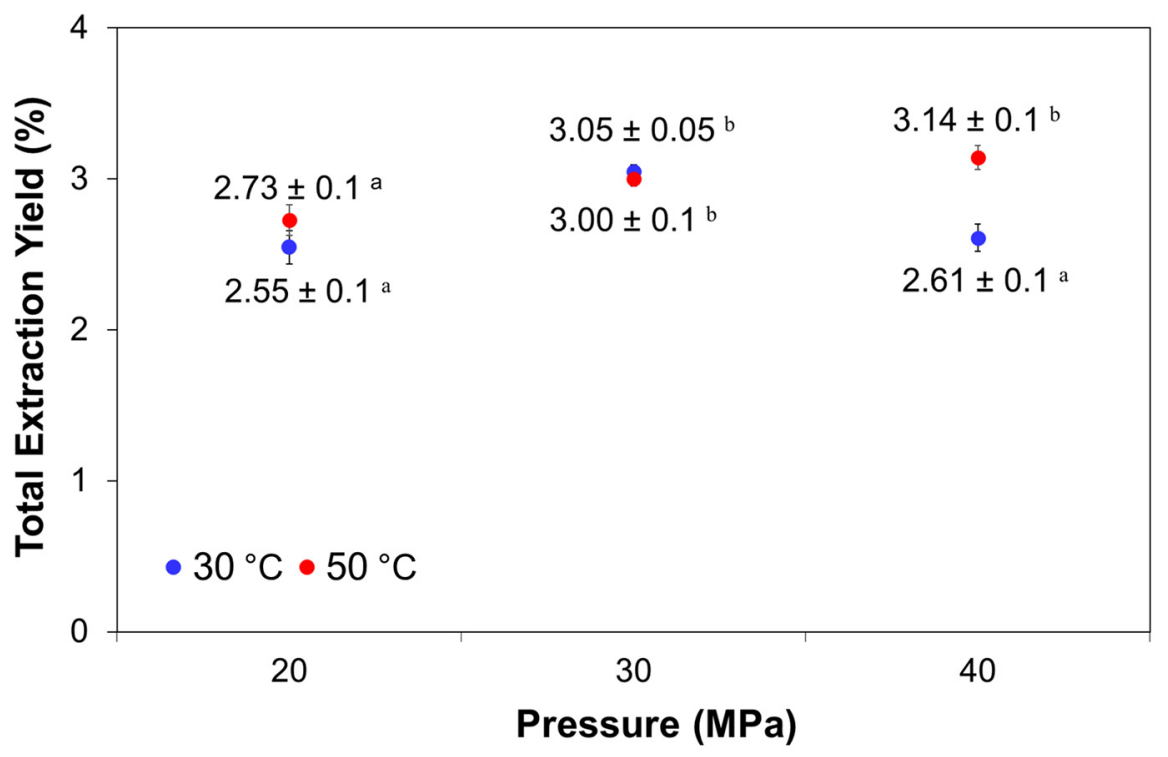

Figure 1. Total extraction yield obtained from P. tricornutum at different pressure and temperature conditions by supercritical fluid extraction. Different superscripted alphabets $(a, b)$ indicate significant differences $(p<0.05)$.

The results are expressed as the percentage of g extract per $\mathrm{g}$ dry weight of P. tricornutum, and the values were obtained at the end of extraction $(60 \mathrm{~min})$. This extraction time was established as optimal in previous studies on carotenoids from microalgae [30] and was considered profitable for minimizing its operational costs in the process. In general, total extraction yields were slightly affected by the combination of pressure and temperature factors. The highest total yields were without significant differences $(p<0.05)$ between them, if arranged from the highest to the lowest value, at the highest pressure and temperature $\left(40 \mathrm{MPa}\right.$ at $\left.50{ }^{\circ} \mathrm{C}, 3.14 \pm 0.03 \%\right)$, followed by $30 \mathrm{MPa}$ at $30^{\circ} \mathrm{C}$ and $30 \mathrm{MPa}$ at $50{ }^{\circ} \mathrm{C}$ $(3.05 \pm 0.05 \%$ and $3.00 \pm 0.09 \%)$, respectively. On the other hand, the lowest extraction yields, which in turn did not have significant differences $(p<0.05)$ between them, were obtained at $20 \mathrm{MPa}$ at $30{ }^{\circ} \mathrm{C}(2.55 \% \mathrm{w} / \mathrm{w})$ together with the condition of $40 \mathrm{MPa}$ at $30{ }^{\circ} \mathrm{C}$ and $20 \mathrm{MPa}$ at $50{ }^{\circ} \mathrm{C}$, which were 2.61 and $2.73 \% w / w$, respectively (Figure 1 ).

As shown in Table 1 and the operating conditions, increasing the pressure at constant temperature increases the $\mathrm{CO}_{2}$ density from 0.890 to $0.988 \mathrm{~g} / \mathrm{mL}$ for pressures of $20-40 \mathrm{MPa}$ at $30^{\circ} \mathrm{C}$ and from 0.784 to $0.923 \mathrm{~g} / \mathrm{mL}$ for pressures of $20-40 \mathrm{MPa}$ at $50{ }^{\circ} \mathrm{C}$. Under these conditions of increased pressure, the total extraction yield (Figure 1) was slightly improved without significant differences $(p<0.05)$ for $30 \mathrm{MPa}$ at $30^{\circ} \mathrm{C}$ and $50^{\circ} \mathrm{C}$, as well as at $40 \mathrm{MPa}$ at $50{ }^{\circ} \mathrm{C}$, except for the conditions of $20 \mathrm{MPa}$ at $30^{\circ} \mathrm{C}$ and $50{ }^{\circ} \mathrm{C}$ and that of $40 \mathrm{MPa}$ at $30{ }^{\circ} \mathrm{C}$. In the pressure range of 30 to $40 \mathrm{MPa}$ at $30^{\circ} \mathrm{C}$, a decrease in yield was observed, 
and it could be due to the volatility of the extracts under these SFE conditions, or the component solubility is lowered as the polarity and/or the molecular weights of the solutes are increased [19].

Table 1. Fucoxanthin purity and recovery of extracts from P. tricornutum biomass obtained by supercritical fluid extraction under different extraction conditions.

\begin{tabular}{|c|c|c|c|c|c|}
\hline \multicolumn{2}{|c|}{ SFE Conditions } & \multicolumn{2}{|r|}{$\mathrm{CO}_{2}$} & \multicolumn{2}{|c|}{ Fucoxanthin } \\
\hline $\begin{array}{c}\mathbf{P} \\
(\mathrm{MPa})\end{array}$ & $\begin{array}{c}\mathrm{T} \\
\left({ }^{\circ} \mathrm{C}\right)\end{array}$ & $\begin{array}{l}\text { Density } \\
(\mathrm{g} / \mathrm{mL})\end{array}$ & $\begin{array}{l}\text { Superficial Velocity } \\
(\mathrm{mm} / \mathrm{s})\end{array}$ & $\begin{array}{c}\text { Purity } \\
\text { (mg/g Extract) }\end{array}$ & $\begin{array}{l}\text { Recovery } \\
(\% w / w)\end{array}$ \\
\hline 20 & 30 & 0.890 & 0.426 & $11.07 \pm 0.46^{\mathrm{a}}$ & $2.87 \pm 0.12^{\mathrm{a}}$ \\
\hline 20 & 50 & 0.784 & 0.484 & $8.56 \pm 0.14^{\mathrm{a}}$ & $2.38 \pm 0.04^{\mathrm{a}}$ \\
\hline 30 & 30 & 0.948 & 0.401 & $60.62 \pm 0.40^{\mathrm{d}}$ & $18.82 \pm 0.12^{\mathrm{e}}$ \\
\hline 30 & 50 & 0.870 & 0.436 & $37.89 \pm 1.00^{\mathrm{c}}$ & $11.59 \pm 0.31^{\mathrm{d}}$ \\
\hline 40 & 30 & 0.988 & 0.384 & $29.06 \pm 1.63^{b}$ & $4.76 \pm 0.19^{b}$ \\
\hline 40 & 50 & 0.923 & 0.411 & $26.67 \pm 2.08^{b}$ & $8.53 \pm 0.66^{c}$ \\
\hline
\end{tabular}

Acronyms: SFE (supercritical fluid extraction); P (pressure); and T (temperature). Different superscripted alphabets $(a-e)$ indicate significant differences $(p<0.05)$ and the data are expressed as mean \pm standard deviation $(n=3$, $\mathrm{SD} \leq 5 \%)$.

Table 1 also shows the purity, calculated as mg fucoxanthin extracted by SFE per $g$ of total extract, and recovery, calculated as the percentage of the weight of fucoxanthin extracted by conventional extraction per grams of biomass as the reference weight of this pigment (equal to $9.82 \pm 0.70 \mathrm{mg} / \mathrm{g}$ biomass) from of $P$. tricornutum. The different temperature and pressure conditions had a significant effect on these fucoxanthin variables, according to Tukey's test. Particularly, the highest fucoxanthin purity and recovery were reached for a pressure of $30 \mathrm{MPa}$ at $30{ }^{\circ} \mathrm{C}(60.62 \pm 0.40 \mathrm{mg} / \mathrm{g}$ and $18.82 \pm 0.12 \% \mathrm{w} / \mathrm{w}$, respectively), being significant $(p<0.05)$ for the rest of the processes. Under these conditions, the density and superficial $\mathrm{CO}_{2}$ velocity were $0.948 \mathrm{~g} / \mathrm{mL}$ and $0.401 \mathrm{~mm} / \mathrm{s}$, respectively, being the second-highest density and lowest superficial velocity, exceeded only by $30{ }^{\circ} \mathrm{C}$ and $40 \mathrm{MPa}$, whose values were $0.988 \mathrm{~g} / \mathrm{mL}$ and $0.384 \mathrm{~mm} / \mathrm{s}$. However, in this treatment, the purity and recovery of fucoxanthin were not the highest. As shown in Table 1, the values of the superficial $\mathrm{CO}_{2}$ velocities were in the range of $0.384-0.484 \mathrm{~mm} / \mathrm{s}$, indicating slight variation, because the mass flow rate $\left(3.62 \mathrm{~g} \mathrm{CO}_{2} / \mathrm{min}\right)$ and the area of the extraction vessel $\left(1589 \mathrm{~cm}^{2}\right)$ were constant, the variations were only due to the density of $\mathrm{CO}_{2}$ that depends on temperature and pressure.

At low temperatures, the purity was higher than that at high temperatures under the same pressure values. This tendency was similar for fucoxanthin recoveries except for $40 \mathrm{MPa}$ and $50{ }^{\circ} \mathrm{C}$, which was approximately two-fold higher than that at $40 \mathrm{MPa}$ and $30^{\circ} \mathrm{C}$. In contrast, at low pressure and under both temperature conditions, fucoxanthin purity and recovery were the lowest.

The particle size distribution is another important parameter in SFE as it directly affects the porosity and physical properties of the extraction bed. The particle diameter is inversely proportional to the total extraction yield [31,32]. On the other hand, a reduction in the final particle diameter increases the surface-to-volume ratio of the substrate [33]. The mean particle size of the Phaeodactylum tricornutum powder was $\mathrm{D}_{\mathrm{P}}=0.074 \pm 0.004 \mathrm{~mm}$, which is considered an ultrafine powder. Crampon et al. [34] reported that the smaller the particle, the faster the kinetics of the extraction, thus higher the yields. The disintegration of cells is essential in the recovery of intracellular products from algae.

The effect of temperature on extraction yield is more complex than that of pressure. This behavior is known as "crossover pressure" and is defined as the point where the vapor pressure of the compounds in the extract is more pronounced than the effect of solvent density over the solubility of the compounds [35,36]. The crossover region is a phenomenological observation that is supported by a relevant number of experimental studies. This phenomenon refers to the regions of temperature and pressure in the near-critical fluid state where the solute solubility decreases with an isobaric increase in temperature [37]. 
The effect of temperature on solubility is complex, and the crossover of the solubility isotherm occurs when pressure is considered as a variable. This phenomenon is affected by solvent density and solute vapor pressure. The vapor pressure increases when temperature and solubility increase; on the contrary, density and solvent power decrease. Consequently, solubility decreases because the density of the solvent is the dominant factor. After passing the crossover area, and when the temperature is increased, the vapor pressure of the solute becomes a dominant factor, and the solubility increases. However, this contrasting behavior is often attributed to solvent density and solute vapor pressure [38].

Foster et al. [39] reported that crossover pressure is a phenomenological observation that appears to reflect a characteristic of the solute-solvent system. Furthermore, it is also of fundamental significance in providing a direct indicator of the reliability and consistency of experimental solubility data. As a consequence, it may also be used to introduce a phenomenological constraint on thermodynamic models proposed to describe solutesupercritical fluid phase equilibria. This means that, at pressures lower than the crossover pressure, the effect of $\mathrm{CO}_{2}$ density is more relevant, whereas for pressures higher than the crossover pressure, the effect of vapor pressure at the determined temperature is more relevant for increasing the extraction yield. This is a common behavior for carotenoids obtained by SFE from vegetable matrices [37].

Fabrowska et al. [40] extracted carotenoids and phenolic compounds from the freshwater macroalgae Cladophora glomerata by optimization of the same parameters included in our study (temperature, pressure, and \% ethanol as a co-solvent). The extraction yields were less than our yields without the use of extractants such as $0.6-0.9 \% w / w$. The higher value of carotenoids recovery, represented with fucoxanthin as a majority, was $6.17 \pm 0.24 \mathrm{mg} / \mathrm{g}$ of the extract under $\sim 30 \mathrm{MPa}$ and $50^{\circ} \mathrm{C}$, being similar conditions, except for the temperature. Ruiz-Domínguez et al. [41] used a Box-Behnken design with desirability function to determine the bioactive composition from the microalga Isochrysis galbana by SFE, and the parameters studied were pressure (20-40 MPa), temperature $\left(40-60{ }^{\circ} \mathrm{C}\right)$, and co-solvent ( $0-8 \%$ ethanol) with a $\mathrm{CO}_{2}$ flow rate of $7.2 \mathrm{~g} / \mathrm{min}$ for $120 \mathrm{~min}$. The extraction yield without the presence of ethanol was in a similar range (from $1.09 \%$ to $2.28 \% w / w$ ), and the highest was $2.28 \pm 0.11 \% w / w$ under $40 \mathrm{MPa}$ at $50^{\circ} \mathrm{C}$. They also determined total carotenoids recovery (included fucoxanthin) with an optimum value of $16.61 \pm 0.74 \%$ at $40 \mathrm{MPa}$ and $50{ }^{\circ} \mathrm{C}$ without co-solvent and $77.93 \pm 2.87 \%$ at $30 \mathrm{MPa}, 60^{\circ} \mathrm{C}$, and $8 \% v / v$ ethanol. Roh et al. [42] extracted fucoxanthin and polyphenols from the brown macroalga Undaria pinnatifida using $\mathrm{SCO}_{2}$ and ethanol as co-solvent. The highest yields of fucoxanthin in the presence of ethanol were at $\sim 20 \mathrm{MPa}$ at $\sim 50{ }^{\circ} \mathrm{C}$ with a value of fucoxanthin recovery much lower than our results (approximately $0.00753 \mu \mathrm{g}$ fucoxanthin per g freeze-dried sample). Therefore, our results showed that an increase in pressure (from 20 to $30 \mathrm{MPa}$ ) at a constant temperature $\left(30^{\circ} \mathrm{C}\right)$ increased the solvating power of carbon dioxide as supercritical fluids favoring fucoxanthin extraction. However, the temperature is a sensitive factor at high ranges, as it can degrade the targeted compound even though it can increase the solubility of this component [43].

Although all results of yield and recovery of fucoxanthin might be improved, the optimal conditions of pressure and temperature for the highest purity and recovery of fucoxanthin were $30 \mathrm{MPa}$ and $30^{\circ} \mathrm{C}$ and were selected for evaluating the behavior under ethanol as an extractant by SFE.

\subsection{Effects of Ethanol as a Co-Solvent Factor on the Yield of Fucoxanthin from Phaeodactylum tricornutum}

Many studies have reported that the use of ethanol as an extractant improves the yields of fucoxanthin due to its polarity and affinity with carotenoid molecules $[44,45]$. The optimal pressure and temperature for the highest purity and recovery of fucoxanthin along with the presence of co-solvent were used for evaluating the effect on the extraction process. Figure 2 shows the total extraction yield obtained under different concentrations of ethanol from $10 \%$ to $50 \% v / v$. Here, the co-solvent improved the extraction yield, being 
at $30 \% v / v$ of ethanol, the highest value was obtained with $24.41 \% w / w$, followed by $20 \% v / v$ of co-solvent with a value of $14.28 \% \mathrm{w} / \mathrm{w}$. However, the lowest value was obtained at $10 \%$ and $50 \% v / v$ of ethanol, with $5.65 \%$ and $5.18 \% w / w$ of total extraction yields, respectively.

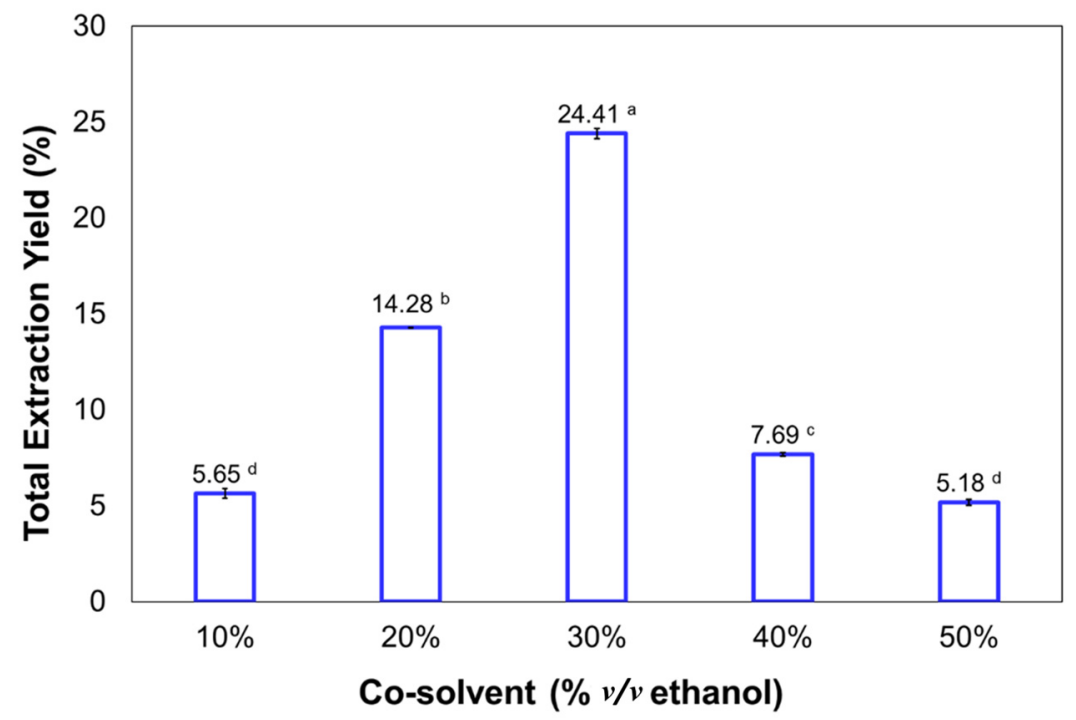

Figure 2. Total extraction yield obtained from P. tricornutum at different concentrations of co-solvent under $30 \mathrm{MPa}$ and $30^{\circ} \mathrm{C}$ by supercritical fluid extraction. Different superscripted alphabets (a-d) indicate significant differences $(p<0.05)$ and mean \pm standard deviation $(\mathrm{SD} \leq 5 \%, n=3)$.

In general, the effect of co-solvent was significant; 30\% $v / v$ ethanol improved total yield to 8-fold higher than that using $30 \mathrm{MPa}, 30{ }^{\circ} \mathrm{C}$, and only carbon dioxide as a solvent. Many studies have reported that SFE is an excellent technique for the selective extraction of bioactive compounds such as carotenoids from various microalgae [16,43,46]. As a general rule, the extraction improves when $\mathrm{SCO}_{2}$ is used, whereas the presence of co-solvent or extractant such as ethanol enhances the efficiency of the supercritical process but disparages the selectivity [16].

On the other hand, Table 2 shows fucoxanthin purity and recovery under $30 \mathrm{MPa}$ and $30{ }^{\circ} \mathrm{C}$ at different percentages of co-solvent.

Table 2. The purity and recovery of fucoxanthin from the P. tricornutum biomass obtained by supercritical fluid extraction under $30 \mathrm{MPa}$ and $30{ }^{\circ} \mathrm{C}$ at different concentrations of co-solvent conditions.

\begin{tabular}{cccc}
\hline $\begin{array}{c}\text { Co-Solvent } \\
\text { (Ethanol, \% v/v) }\end{array}$ & $\begin{array}{c}\text { Ethanol + } \mathbf{C O}_{\mathbf{2}} \\
\text { (g/min) }\end{array}$ & $\begin{array}{c}\text { Fucoxanthin Purity } \\
\text { (mg/g Extract) }\end{array}$ & $\begin{array}{c}\text { Fucoxanthin Recovery } \\
(\mathbf{\%} \text { w/w) }\end{array}$ \\
\hline 10 & 3.406 & $22.06 \pm 1.92^{\mathrm{ab}}$ & $12.69 \pm 1.14^{\mathrm{a}}$ \\
20 & 3.208 & $28.65 \pm 0.49^{\mathrm{b}}$ & $41.68 \pm 0.71^{\mathrm{b}}$ \\
30 & 3.002 & $13.75 \pm 0.65^{\mathrm{a}}$ & $34.17 \pm 1.61^{\mathrm{b}}$ \\
40 & 2.801 & $85.03 \pm 7.67^{\mathrm{c}}$ & $66.60 \pm 6.00^{\mathrm{c}}$ \\
50 & 2.591 & $74.73 \pm 2.45^{\mathrm{c}}$ & $39.46 \pm 1.29^{\mathrm{b}}$ \\
\hline
\end{tabular}

Different superscripted alphabets $(\mathrm{a}-\mathrm{c})$ indicate significant differences $(p<0.05)$ and the data are expressed as mean \pm standard deviation $(n=3, \mathrm{SD} \leq 5 \%)$.

The highest values with no significant differences in fucoxanthin purity were $85.03 \pm 7.67 \mathrm{mg} / \mathrm{g}$ and $74.73 \pm 2.45 \mathrm{mg} / \mathrm{g}$ extract using 40 and $50 \%$ v/v of ethanol, respectively. However, the lowest purity was $13.75 \pm 0.65 \mathrm{mg} / \mathrm{g}$ extract at $30 \% \mathrm{v} / \mathrm{v}$ of co-solvent despite the extraction yield being higher in this condition.

The highest fucoxanthin recovery with significant differences among others was $66.60 \pm 6.00 \% w / w$ under $40 \% v / v$ of ethanol, whereas the lowest was $12.69 \pm 1.14 \% w / w$ using $10 \% \mathrm{v} / \mathrm{v}$ of ethanol. The fucoxanthin purity and recovery reached the maximum 
value under the same conditions of $30 \mathrm{MPa}, 30{ }^{\circ} \mathrm{C}$, and $40 \% v / v$ ethanol. As reported by Gómez-Loredo et al. [47], an increasing concentration of co-solvent could induce a decrease in the purity and recovery of fucoxanthin as other compounds that were the part of the extract could transfer with this carotenoid. At times, up to a certain value, the addition of co-solvent has no further effect. This could happen at $50 \% v / v$ ethanol where fucoxanthin purity and recovery begin to decrease.

Extraction of fucoxanthin from different natural sources using conventional solvent, pressurized liquid extraction, or supercritical fluids extraction has been reported. For example, Conde et al. [48] showed ethanol concentration $(0.5-10 \% v / v)$ as a significant factor in the supercritical $\mathrm{CO}_{2}$ extraction process from the macroalgae Sargassum muticum. The improvement in ethanol concentration resulted in total yields up to 3 times higher, radical scavenging capacity up to 2.5 times higher, and fucoxanthin extraction yield up to 90 times higher, thus reaching approximately $12 \mathrm{mg}$ fucoxanthin/100 $\mathrm{mg}$ dry biomass under $20 \mathrm{MPa}$ at $30{ }^{\circ} \mathrm{C}$ and $10 \%$ v/v ethanol. Gilbert-López et al. [49] compared MAE and PLE as green techniques for the extraction of bioactive compounds from P. tricornutum. The total yield $(23.95 \% \mathrm{w} / \mathrm{w})$, fucoxanthin purity, and its recovery $(32.29 \mathrm{mg} / \mathrm{g}$ extract and $54.41 \% w / w$, respectively) were the highest under $50{ }^{\circ} \mathrm{C}$ and $100 \%$ ethanol using PLE. Our results of fucoxanthin purity and recovery are higher than these results, although the P. tricornutum strain described by Gilbert-López et al. [49] reached up to 1.5-times higher concentration of fucoxanthin by conventional extraction than our results (maceration in acetone during $24 \mathrm{~h}$ at room temperature was around of $59.5 \pm 4.7 \mathrm{mg} / \mathrm{g}$ extract). All results corroborated that $P$. tricornutum is an important source of bioactive compounds such as fucoxanthin and is better than other species such as macroalgae.

\subsection{Biochemical Composition and the Effects of SFE on AD Using P. tricornutum}

Table 3 presents the physicochemical characterization of the diatom P. tricornutum and supercritical-fluid-extracted P. tricornutum.

Table 3. Characteristics of P. tricornutum before and after supercritical fluid extraction.

\begin{tabular}{ccc}
\hline Parameters & P. tricornutum & Supercritical Fluid Extracted P. tricornutum \\
\hline $\mathrm{TS}(\mathrm{mg} / \mathrm{kg})$ & $891,635 \pm 1485$ & $920,030 \pm 1025$ \\
$\mathrm{MS}(\mathrm{mg} / \mathrm{kg})$ & $182,375 \pm 2030$ & $200,420 \pm 4005$ \\
$\mathrm{VS}(\mathrm{mg} / \mathrm{kg})$ & $709,260 \pm 3520$ & $719,610 \pm 1090$ \\
$\mathrm{VS}(\%)$ & 79.55 & 78.22 \\
Humidity $(\%)$ & $10.84 \pm 0.07$ & $8.00 \pm 0.05$ \\
$\mathrm{~N}-\mathrm{TKN}(\mathrm{mg} / \mathrm{kg})$ & $56,167 \pm 173$ & $42,937 \pm 4687$ \\
$\mathrm{P}_{\mathrm{T}}-\mathrm{P}_{2} \mathrm{O}_{5}(\mathrm{mg} / \mathrm{g})$ & $1.692 \pm 0.038$ & $0.433 \pm 0.004$ \\
$\mathrm{Cr}(\mathrm{mg} / \mathrm{kg})$ & $10.9 \pm 0.25$ & $16.36 \pm 0.10$ \\
$\mathrm{Cd}(\mathrm{mg} / \mathrm{kg})$ & $2.05 \pm 0.30$ & $4.26 \pm 0.65$ \\
$\mathrm{~Pb}(\mathrm{mg} / \mathrm{kg})$ & $3.25 \pm 0.50$ & $5.11 \pm 0.70$ \\
$\mathrm{Ni}(\mathrm{mg} / \mathrm{kg})$ & $4.11 \pm 0.15$ & $6.48 \pm 0.68$ \\
$\mathrm{Zn}(\mathrm{mg} / \mathrm{kg})$ & $180.30 \pm 0.85$ & $255.43 \pm 0.68$ \\
$\mathrm{Cu}(\mathrm{mg} / \mathrm{kg})$ & $12.95 \pm 0.17$ & $18.84 \pm 0.08$ \\
\hline
\end{tabular}

Acronyms: TS: total solids, MS: mineral solids, VS: volatile solids, N-TKN: total Kjeldahl nitrogen, $\mathrm{P}_{\mathrm{T}}-\mathrm{P}_{2} \mathrm{O}_{5}$ : total phosphorous.

As shown, most of the analyzed parameters have maintained similar values in both groups. Only metal content, which increased in all cases after SFE, and the $\mathrm{P}_{\mathrm{T}}-\mathrm{P}_{2} \mathrm{O}_{5}$ parameter decreased by four times after SFE. It should be highlighted that the metal content reached non-toxic or inhibiting concentrations. The maintenance of nutrients such as nitrogen (N-TKN) or phosphorous $\left(\mathrm{P}_{\mathrm{T}}-\mathrm{P}_{2} \mathrm{O}_{5}\right)$ in the diatom P. tricornutum is essential for the microorganisms responsible for performing $\mathrm{AD}$.

The comparison of the biochemical composition of P. tricornutum biomass and other strains is presented in Table 4. Biogas production from microalgae depends on their biochemical composition and other factors such as operating conditions, cell wall nature, $\mathrm{C} / \mathrm{N}$ ratios and ammonia release, and sodium in marine species [50-52]. The analysis of the 
biochemical composition may help in the comprehension of the methane yields obtained. The best theoretical methane yields obtained are for lipids, followed by proteins and carbohydrates, with values $1.014 \mathrm{~L} \mathrm{CH}_{4} / \mathrm{g} \mathrm{VS}, 0.851 \mathrm{~L} \mathrm{CH}_{4} / \mathrm{g} \mathrm{VS}$, and $0.415 \mathrm{~L} \mathrm{CH}_{4} / \mathrm{g}$ VS, respectively [51]. These values could be accurate considering the composition of the specific microalga species.

Generally, the exhausted diatom has the lowest macronutrient content due to the extraction process, highlighting the decrease in lipid and protein content by more than half. The biochemical composition of pretreated P. tricornutum markedly decreased with the extraction of $68.99 \%$ and $60.19 \%$ of lipids and proteins, respectively, until the values of $5.01 \pm 0.01 \%$ and $14.41 \pm 0.62 \% w / w$, respectively, were obtained. However, only $29.15 \%$ of carbohydrates were extracted. On the other hand, the protein content differed significantly $(p \leq 0.05)$ among the strains, followed by lipid and carbohydrate contents. The protein content ranged from $38.8 \pm 0.11 \%$ to $26.95 \pm 0.05 \% w / w$ (excluding $P$. tricornutum after SFE) with P. tricornutum F\&M-M4 showing the highest value (Table 4). For carbohydrate content, all strains showed similar values with slight differences. Particularly, the carbohydrate content of $P$. tricornutum in our study was higher $(18.80 \pm 1.12 \% w / w)$ than the P. tricornutum carbohydrate content $(16.91 \pm 1.61 \% w / w)$ reported by Di Lena et al. [53]. P. tricornutum F\&M-M4 had the highest lipid content, followed by a diatom described by Bernaerts et al. [54] $(17.1 \pm 0.9 \% w / w)$. In the case of extracted P. tricornutum, the lipid content was significantly decreased compared with the initial content in the biomass before extraction because especially the lipid fraction was recovered through supercritical $\mathrm{CO}_{2}$-extraction technology.

Globally, such results have confirmed P. tricornutum as complete and nutritive biomass; hence, it is important in aquaculture feeds and food applications [5,9,10,55]. Nevertheless, the biochemical compositions of $P$. tricornutum found in previous studies are variable and highly dependent on strains, culturing conditions, and growth stages $[54,56]$.

Table 4. Biochemical composition of the diatom P. tricornutum before and after supercritical fluid extraction compared with the composition reported in previous studies.

\begin{tabular}{|c|c|c|c|c|}
\hline Strain/Diatom & $\begin{array}{l}\text { Proteins } \\
(\% w / w)\end{array}$ & $\begin{array}{l}\text { Carbohydrates } \\
(\% \text { w/w })\end{array}$ & $\begin{array}{l}\text { Lipids } \\
(\% w / w)\end{array}$ & References \\
\hline P. tricornutum & $36.20 \pm 1.20^{\mathrm{d}}$ & $18.80 \pm 1.12^{b}$ & $16.15 \pm 0.75^{c}$ & In this study \\
\hline Supercritical fluid extracted P. tricornutum & $14.41 \pm 0.62^{\mathrm{a}}$ & $13.32 \pm 0.45^{\mathrm{a}}$ & $5.01 \pm 0.01^{\mathrm{a}}$ & In this study \\
\hline P. tricornutum F\&M-M4 & $38.8 \pm 0.11^{\mathrm{e}}$ & $11.0 \pm 0.70^{\mathrm{a}}$ & $20.5 \pm 0.54^{d}$ & [57] \\
\hline P. tricornutum & $29.4 \pm 0.4^{c}$ & $10.5 \pm 0.26^{* a}$ & $17.1 \pm 0.9^{c}$ & [54] \\
\hline P. tricornutum & $26.95 \pm 0.05^{b}$ & $16.91 \pm 1.61^{\mathrm{b}}$ & $12.73 \pm 0.13^{b}$ & [53] \\
\hline
\end{tabular}

* Sum of storage polysaccharides (SPS) and cell wall polysaccharides (CWPS). Note: Different superscripted alphabets $(\mathrm{a}-\mathrm{e})$ indicate significant differences $(p<0.05)$ and the data are expressed as mean \pm standard deviation $(n=3, \mathrm{SD} \leq 5 \%)$. Nucleic acids and ash account for the percentage left to make $100 \% \mathrm{wt}$ of proximal composition.

As shown in Table 4, our supercritical-fluid-extracted P. tricornutum or exhausted biomass was rich in proteins, carbohydrates, and to a lesser extent in lipids. This could be used in different integrated processes in algae biorefinery. Hence, in our study, the production of bioenergy in the form of biogas was evaluated.

\subsection{BMP of Diatom P. tricornutum and Extracted P. tricornutum by SFE}

Typically, the yield of biogas obtained by AD is associated with the biochemical composition and VS content of the biomass used as a substrate. Particularly, the AD of microalgae can be affected by different factors such as low $\mathrm{C} / \mathrm{N}$ ratio, thick cell walls banking on the microalgal genus, and high concentrations of sodium for marine species [50,52,58].

P. tricornutum is the only species in the genus Phaeodactylum, which is rich in bioactive compounds such as fucoxanthin and fatty acids $[10,55]$. However, this genus has a silicious wall, one of the main drawbacks when considering the microalgae for AD that could affect the results of this process. When intracellular compounds of interest such as fucoxanthin are extracted by SFE from microalgae, the action of temperature, pressure, and the use of 
ethanol as a co-solvent can be considered as a pretreatment. SFE helps in the extraction of fucoxanthin, but the breakage of cell structures also favors the release of other compounds, which facilitates the action of microorganisms that perform the hydrolytic steps of AD. After SFE, the cell wall and structure breaks to some extent, and the remaining compounds and cell material are released into the surrounding environment, which can be used as substrates to feed anaerobic microorganisms [59].

The methane yields obtained for the whole P. tricornutum and the extracted diatom were 77.2 $\pm 3.85 \mathrm{LSTP} \mathrm{CH}_{4} / \mathrm{kg}$ VS and $56.7 \pm 1.90 \mathrm{LSTP} \mathrm{CH}_{4} / \mathrm{kg}$ VS, respectively (Figure 3).

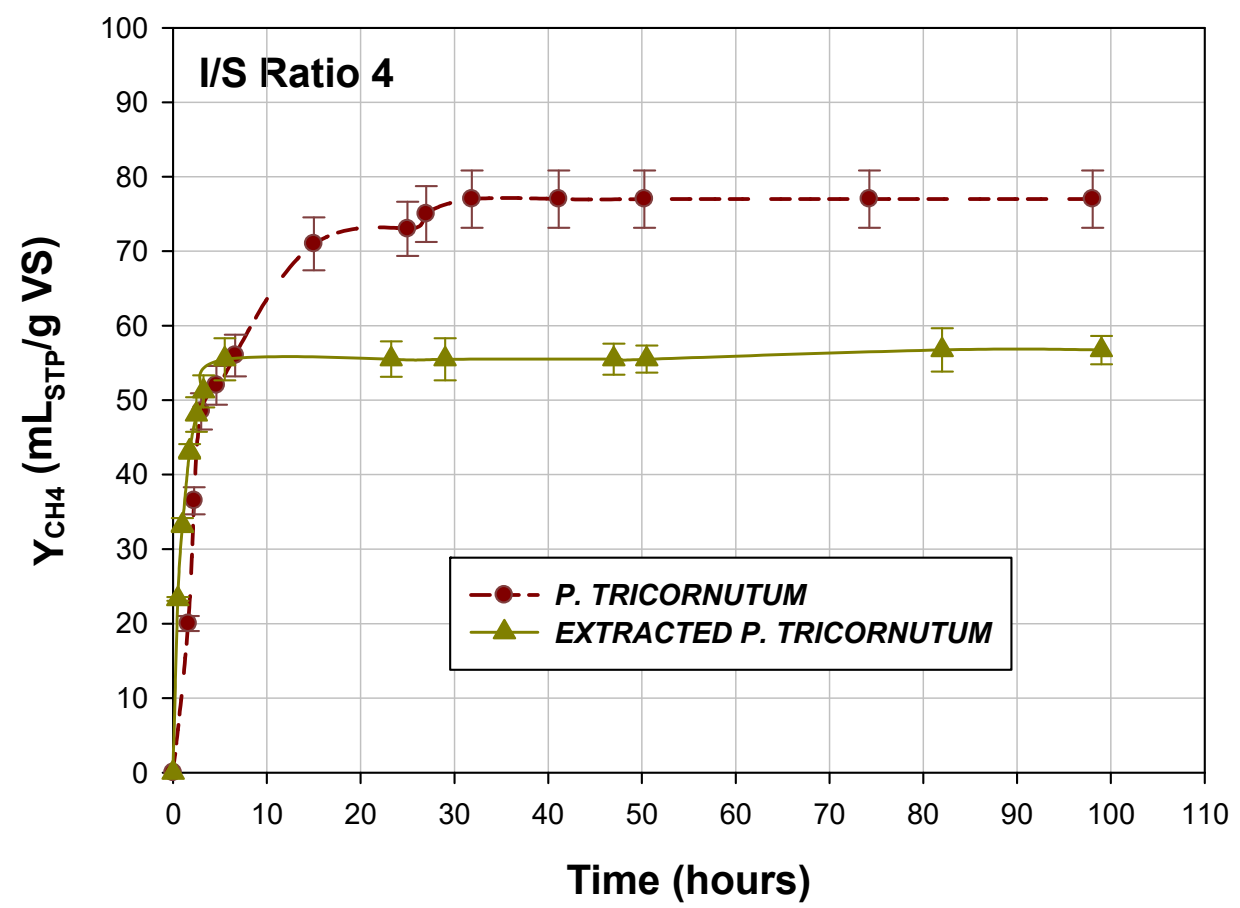

Figure 3. Methane yields obtained for diatom P. tricornutum and supercritical-fluid-extracted microalga P. tricornutum.

In both cases, a methane yield of around $55 \mathrm{LSTP} \mathrm{CH}_{4} / \mathrm{kg}$ VS was obtained in less than $10 \mathrm{~h}$, highlighting the fast biodegradability of the substrate and microbial activity at the beginning of AD. Caporgno et al. [60] obtained methane yields of $257 \pm 8 \mathrm{~mL}$ of $\mathrm{CH}_{4} / \mathrm{g}$ VS and $180 \pm 6 \mathrm{~mL}$ of $\mathrm{CH}_{4} / \mathrm{g}$ VS, respectively, for $P$. tricornutum after lipid extraction for biodiesel production with traditional solvents such as hexane and methanol/hexane mix-

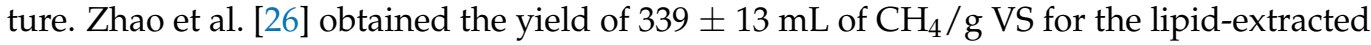
microalgal biomass using hexane and evaporating it after the extraction at $105{ }^{\circ} \mathrm{C}$ in a hood. Studies on the AD of P. tricornutum are limited, and the methane yields reported by Caporgno et al. [60], Zhao et al. [26], Frigon et al. [61], or Zamalloa et al. [62] could not be compared with the yields obtained in the present study because the extraction methods were not the same, nor did the extracted compounds include fucoxanthin, and the extraction of different compounds can affect AD methane yields differently.

In addition, a high or low concentration of a co-solvent (as a remainder) at the end of the extraction process of added high-value products can increase methane production when they are biodegradable. In our study, the methane yield obtained for the whole diatom was higher $\left(77.2 \pm 3.85 \mathrm{LSTP} \mathrm{CH}_{4} / \mathrm{kg}\right.$ VS) than that obtained for the extracted diatom (56.7 $\left.\pm 1.90 \mathrm{LSTP} \mathrm{CH}_{4} / \mathrm{kg} \mathrm{VS}\right)$, resulting in a $26.6 \%$ reduction in the methane yield obtained from the whole microorganism. However, from the environmental and economic point of view, through the AD of the extracted P. tricornutum, biogas was obtained, which could reduce the energy costs for fucoxanthin extraction by SFE and/or contribute to the reduction in the costs of growing new microalgal biomass conferring the circularity to the process. 


\subsection{Characteristics of Effluents after $A D$}

Table 5 shows the characterization of the effluents or digests obtained after BMP assays of the microalgae P. tricornutum and the supercritical-fluid-extracted P. tricornutum. Conductivity was stable in both microalgae, with values around 17.75 to $18.14 \mathrm{mS} / \mathrm{cm}$ in all effluents obtained and loads assayed. The $\mathrm{pH}$ in these effluents increased with the second load in the BMP assays of both diatoms. The $\mathrm{pH}$ values obtained in the second load of the supercritical-fluid-extracted $P$. tricornutum were $9.05 \pm 0.02$, which are especially high for an anaerobic system, for which the optimal $\mathrm{pH}$ range is from 6.7 to 7.5 , close to neutral ranges. In anaerobic processes and at this $\mathrm{pH}$, VFA and ammonia almost dissociate.

Table 5. Characterization of the effluents or digestates obtained after BMP assays on the diatom P. tricornutum and the supercritical fluid extracted P. tricornutum.

\begin{tabular}{|c|c|c|c|c|}
\hline Variables & $\begin{array}{l}\text { 1st Load } \\
\text { P. Tricornutum }\end{array}$ & $\begin{array}{l}\text { 2nd Load } \\
\text { P. Tricornutum }\end{array}$ & $\begin{array}{c}\text { 1st Load } \\
\text { Supercritical Fluid } \\
\text { Extracted } P \text {. } \\
\text { Tricornutum }\end{array}$ & $\begin{array}{c}\text { 2nd Load } \\
\text { Supercritical Fluid } \\
\text { Extracted } P \text {. } \\
\text { Tricornutum }\end{array}$ \\
\hline $\mathrm{pH}$ & $8.26 \pm 0.01$ & $9.05 \pm 0.02$ & $8.00 \pm 0.02$ & $8.29 \pm 0.01$ \\
\hline Conductivity (mS/cm) & $18.09 \pm 0.02$ & $18.14 \pm 0.03$ & $17.89 \pm 0.01$ & $17.75 \pm 0.01$ \\
\hline T-Alk $\left(\mathrm{mg} \mathrm{CO}{ }_{3} \mathrm{Ca} / \mathrm{L}\right)$ & $9678 \pm 90$ & $10,098 \pm 105$ & $9815 \pm 115$ & $10,300 \pm 95$ \\
\hline VFA (mg C/L) & $134 \pm 10$ & $87 \pm 5$ & $184 \pm 8$ & $154 \pm 5$ \\
\hline $\mathrm{VFA}\left(\mathrm{mgCH} \mathrm{CHOH}_{3} \mathrm{CO}\right)$ & $335 \pm 15$ & $218 \pm 13$ & $525 \pm 20$ & $385 \pm 13$ \\
\hline $\mathrm{TS}(\mathrm{mg} / \mathrm{L})$ & $17,952 \pm 435$ & $18,606 \pm 105$ & $17,900 \pm 80$ & $18,325 \pm 160$ \\
\hline MS (mg/L) & $11,177 \pm 210$ & $11,311 \pm 85$ & $11,940 \pm 250$ & $11,898 \pm 350$ \\
\hline VS (mg/L) & $6775 \pm 225$ & $7295 \pm 40$ & $6260 \pm 100$ & $6620 \pm 430$ \\
\hline $\mathrm{N}-\mathrm{NH}_{4}{ }^{+}(\mathrm{mg} / \mathrm{L})$ & $1472 \pm 60$ & $1653 \pm 50$ & $1265 \pm 5$ & $1290 \pm 10$ \\
\hline TKN (mg/L) & $2013 \pm 25$ & $2169 \pm 25$ & $1720 \pm 10$ & $1812 \pm 15$ \\
\hline $\mathrm{P}_{\mathrm{T}}-\mathrm{P}_{2} \mathrm{O}_{5}(\mathrm{mg} / \mathrm{L})$ & $4.72 \pm 0.02$ & $5.56 \pm 0.02$ & $5.01 \pm 0.02$ & $5.83 \pm 0.02$ \\
\hline $\mathrm{Cu}(\mathrm{mg} / \mathrm{L})$ & $0.28 \pm 0.01$ & $0.17 \pm 0.02$ & $0.10 \pm 0.01$ & $0.05 \pm 0.01$ \\
\hline $\mathrm{Ni}(\mathrm{mg} / \mathrm{L})$ & $0.90 \pm 0.01$ & $0.22 \pm 0.01$ & $0.02 \pm 0.01$ & $<\mathrm{DL}(0.05 \mathrm{mg} / \mathrm{L})$ \\
\hline $\mathrm{Zn}(\mathrm{mg} / \mathrm{L})$ & $0.98 \pm 0.02$ & $0.26 \pm 0.03$ & $0.30 \pm 0.01$ & $<\mathrm{DL}(0.05 \mathrm{mg} / \mathrm{L})$ \\
\hline $\mathrm{Pb}(\mathrm{mg} / \mathrm{L})$ & $6.36 \pm 0.06$ & $5.46 \pm 0.05$ & $0.43 \pm 0.01$ & $0.21 \pm 0.01$ \\
\hline $\mathrm{Cr}(\mathrm{mg} / \mathrm{L})$ & $0.078 \pm 0.002$ & $<\mathrm{DL}(0.05 \mathrm{mg} / \mathrm{L})$ & $2.96 \pm 0.01$ & $<\mathrm{DL}(0.05 \mathrm{mg} / \mathrm{L})$ \\
\hline $\mathrm{Cd}(\mathrm{mg} / \mathrm{L})$ & $0.60 \pm 0.01$ & $0.22 \pm 0.02$ & $0.41 \pm 0.01$ & $<\mathrm{DL}(0.05 \mathrm{mg} / \mathrm{L})$ \\
\hline Acetic acid (mg/L) & $26.80 \pm 2.56$ & $28.4 \pm 4.21$ & $51.80 \pm 5.20$ & $27.95 \pm 4.12$ \\
\hline Propionic acid (mg/L) & $6.12 \pm 0.25$ & $7.69 \pm 2.10$ & $14.48 \pm 2.35$ & $7.23 \pm 1.98$ \\
\hline Isobutiric acid $(\mathrm{mg} / \mathrm{L})$ & $25.00 \pm 1.00$ & $27.54 \pm 1.36$ & $21.67 \pm 1.38$ & $4.87 \pm 5.24$ \\
\hline Butiric acid (mg/L) & $8.35 \pm 1.40$ & $7.63 \pm 1.02$ & $25.89 \pm 3.33$ & $14.23 \pm 3.07$ \\
\hline Isovaleric acid $(\mathrm{mg} / \mathrm{L})$ & $18.25 \pm 3.15$ & $25.08 \pm 3.00$ & $<\mathrm{DL}(0.5 \mathrm{mg} / \mathrm{L})$ & $<\mathrm{DL}(0.5 \mathrm{mg} / \mathrm{L})$ \\
\hline Valeric acid (mg/L) & $<\mathrm{DL}(0.5 \mathrm{mg} / \mathrm{L})$ & $<\mathrm{DL}(0.5 \mathrm{mg} / \mathrm{L})$ & $<\mathrm{DL}(0.5 \mathrm{mg} / \mathrm{L})$ & $<\mathrm{DL}(0.5 \mathrm{mg} / \mathrm{L})$ \\
\hline Caproic acid (mg/L) & $<\mathrm{DL}(0.5 \mathrm{mg} / \mathrm{L})$ & $<\mathrm{DL}(0.5 \mathrm{mg} / \mathrm{L})$ & $<\mathrm{DL}(0.5 \mathrm{mg} / \mathrm{L})$ & $<\mathrm{DL}(0.5 \mathrm{mg} / \mathrm{L})$ \\
\hline
\end{tabular}

Acronyms: T-Alk: total alkalinity, VFA: volatile fatty acids, $\mathrm{PT}-\mathrm{P}_{2} \mathrm{O}_{5}$ : total phosphorous, TS: total solids, MS: mineral solids, VS: volatile solids, N-NH4+: ammoniacal nitrogen, TKN: total Kjeldahl Nitrogen, DL: Detection Limit, Phaeodactylum Tricornutum (P. tricornutum).

Figure 4 shows the values of T-Alk measured in the effluents obtained after the BMP assays of diatom P. tricornutum and supercritical-fluid-extracted P. tricornutum.

T-Alk is an important parameter for AD systems. T-Alk gives anaerobic systems the capacity to cope with $\mathrm{pH}$ fluctuations. Most anaerobic reactors have T-Alks between 1500 and $5000 \mathrm{mg} \mathrm{CaCO}_{3} / \mathrm{L}$, although values above $5000 \mathrm{mg} \mathrm{CaCO}_{3} / \mathrm{L}$ found in some reactors exhibited a slightly negative effect on the process [63]. In the present study, TAlk values of the effluents were high, $9678 \pm 90 \mathrm{mg} \mathrm{CaCO} 3 / \mathrm{L}$ and 10,098 $\pm 105 \mathrm{mg}$ $\mathrm{CaCO}_{3} / \mathrm{L}$ for the first and the second loads assayed with P. tricornutum and $9815 \pm 115$ and $10,300 \pm 95 \mathrm{mg} \mathrm{CaCO}_{3} / \mathrm{L}$ for the first and second loads with supercritical-fluid-extracted P. tricornutum, respectively. This increase in T-Alk could be responsible for the increase in ammonia concentration. The initial growth of ammonia in the media can increase buffer capacity [64]; however, the high concentrations of ammonia can inhibit methanogenesis. 


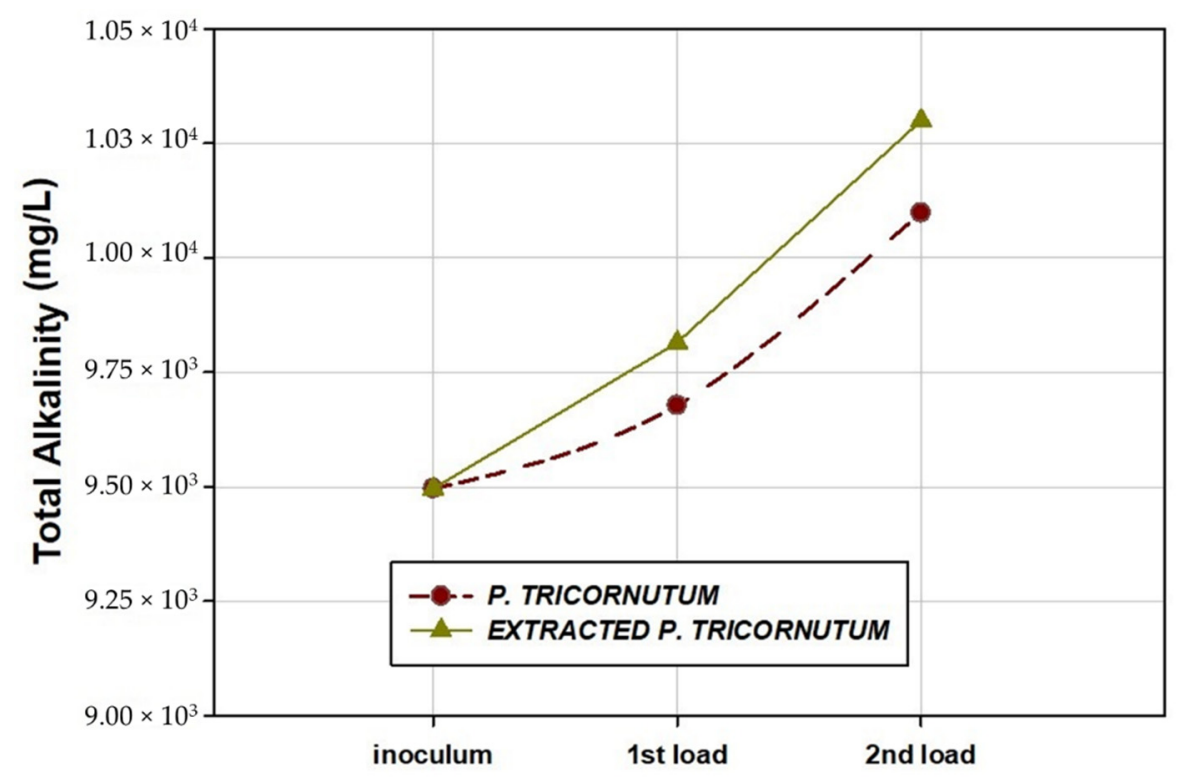

Figure 4. Total alkalinity of the effluents obtained after biochemical methane potential assays (first load and second load) for the diatom P. tricornutum and supercritical-fluid-extracted P. tricornutum.

In anaerobic digesters, ammonium and free ammonia are in equilibrium, and free ammonia, a form of nitrogen, is more dangerous for these systems. Free ammonia concentrations are usually higher at higher $\mathrm{pH}$ and temperatures, reaching an inhibitory concentration of $150 \mathrm{mg} \mathrm{N}-\mathrm{NH}_{3} / \mathrm{L}$ [65]. In the present study, $\mathrm{N}-\mathrm{NH}_{4}{ }^{+}$concentration increased from $1472 \pm 60$ to $1653 \pm 50 \mathrm{mg} / \mathrm{L}$ when moving from the first load to the second load in the reactors digesting $P$. tricornutum. On the other hand, $\mathrm{N}-\mathrm{NH}_{4}{ }^{+}$concentrations were almost constant for the first and second loads of the extracted P. tricornutum, with values of $1265 \pm 5$ and $1290 \pm 10 \mathrm{mg} / \mathrm{L}$ for the first and second load assayed, respectively (Figure 5A).

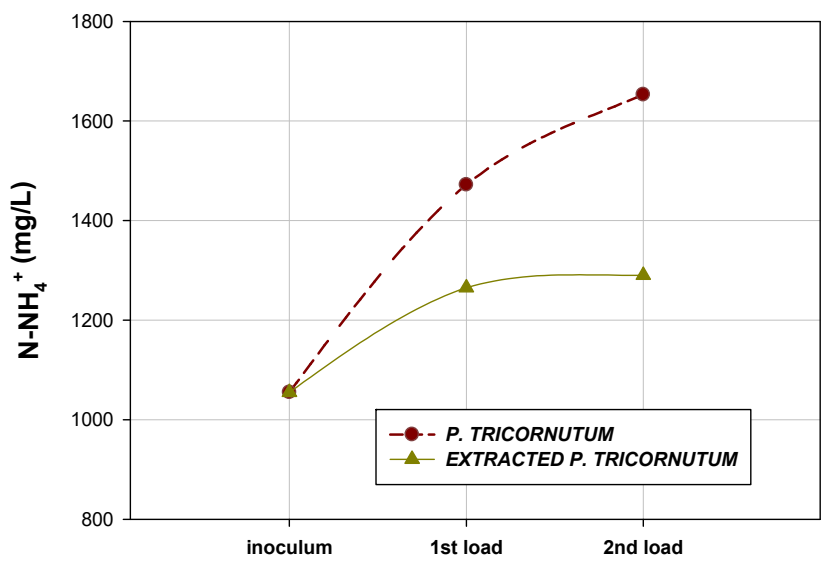

(A)

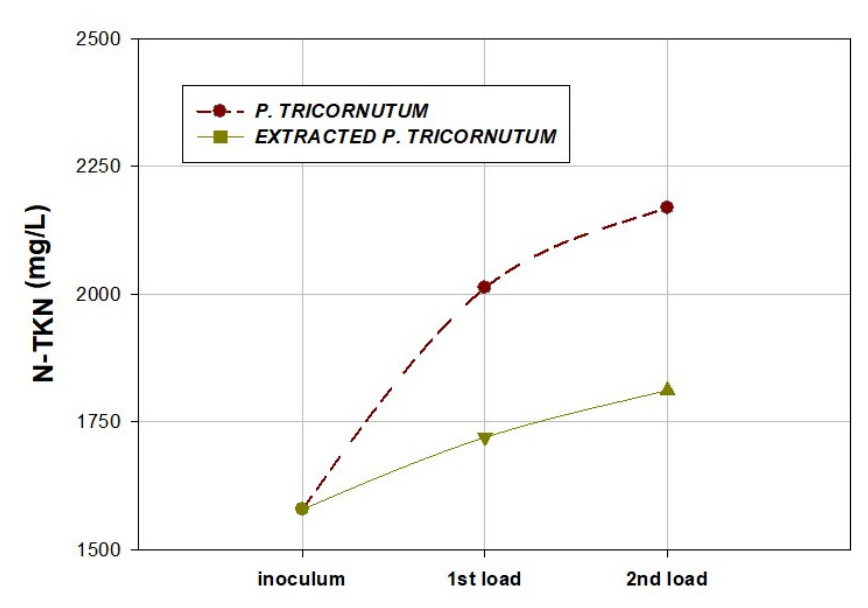

(B)

Figure 5. Ammoniacal nitrogen (A) and total Kjeldahl nitrogen (B) content in the effluents obtained after biochemical methane potential assays (first load and second load) for the diatom P. tricornutum and supercritical-fluid-extracted P. tricornutum.

The values obtained for the whole diatom $P$. tricornutum were high and close to inhibitory values obtained in anaerobic environments, between 1500 and $3000 \mathrm{mg} \mathrm{N}-\mathrm{NH}_{4}{ }^{+} / \mathrm{L}$ [66]. Inhibitory concentration values can be higher in an adapted process; some studies have shown the tolerance of microalgae to ammonia concentrations between $1500-7000 \mathrm{mg} \mathrm{N}^{-\mathrm{NH}_{4}+}$ / $\mathrm{L}$ [67]. 
Factors such as the origin of the inoculum, temperature, and types of substrates may affect this wide range of inhibitory concentrations of $\mathrm{N}-\mathrm{NH}_{4}{ }^{+}$[65].

The N-TKN (Figure 5B) present in the effluents obtained after the first and second load of the diatom $P$. tricornutum were higher than that obtained after the first and second load of the supercritical-fluid-extracted P. tricornutum, obtaining values of $2013 \pm 25 \mathrm{mg} / \mathrm{L}$ and $2169 \pm 25 \mathrm{mg} / \mathrm{L}$ for the first and second loads of the whole P. tricornutum, respectively. These values were lower for the extracted P. tricornutum, $1720 \pm 10$ and $1812 \pm 15 \mathrm{mg} / \mathrm{L}$ for the first and second loads, respectively. These values could be responsible for a $39.8 \%$ reduction in proteins, which decreased from $36.20 \%$ to $14.41 \%(w / w)$ for the diatom P. tricornutum due to SFE, as described in Section 2.3 and Table 4.

Figure 6 shows the VFA evolution in each load studied for the diatom P. tricornutum and supercritical-fluid-extracted P. tricornutum. VFAs in the effluents after the BMP assays showed a decreasing trend at the end of the second load, decreasing values from $195 \pm 5 \mathrm{mg} \mathrm{C} / \mathrm{L}$ to $87 \pm 5 \mathrm{mg} \mathrm{C} / \mathrm{L}$ for the non-extracted diatom and from $190 \pm 10 \mathrm{mg}$ $\mathrm{C} / \mathrm{L}$ to $154 \pm 5 \mathrm{mg} \mathrm{C} / \mathrm{L}$ for the supercritical-fluid-extracted P. tricornutum. The decrease in acidity was an indicator of the presence of an adequate amount of methanogenic bacteria.

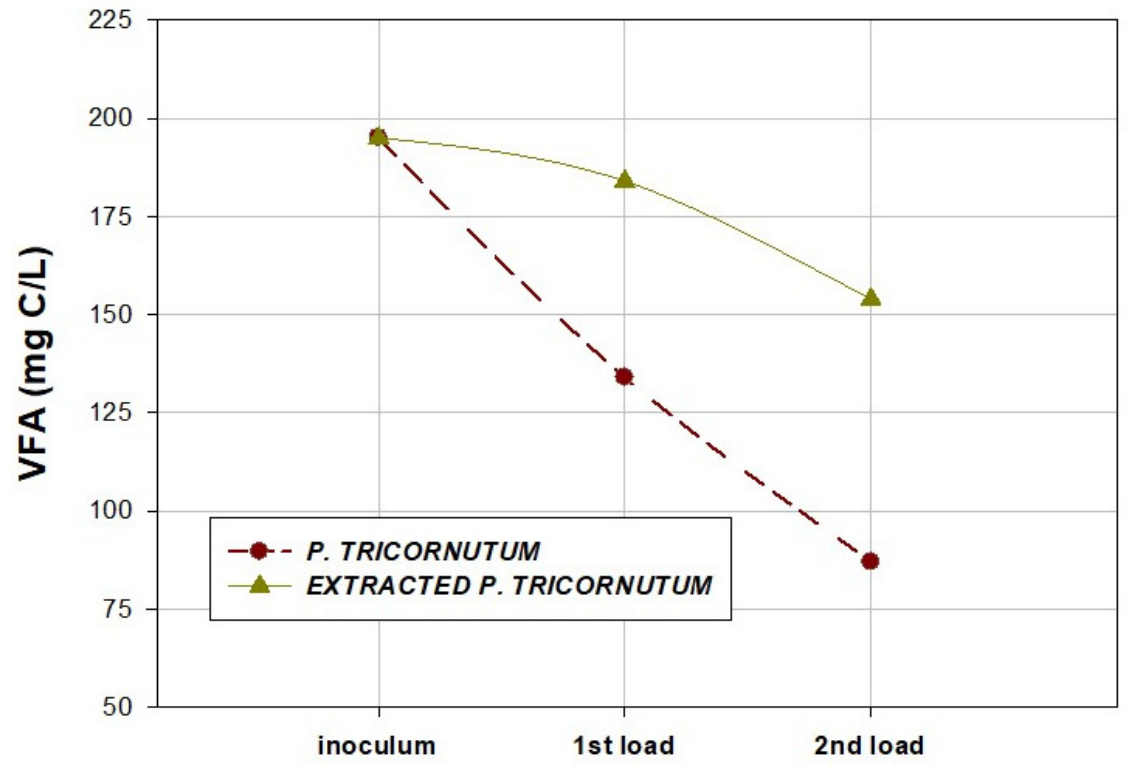

Figure 6. Concentrations of volatile fatty acids (VFA) obtained in the effluents after biochemical methane potential (BMP) assays (first load and second load) for the diatom P. tricornutum and supercritical-fluid-extracted P. tricornutum.

Finally, it seems that metal content provided by the own diatom does not apparently affect the AD process. The use of microalgae (including diatoms) in co-digestion with rich carbon substrates is common for obtaining adequate nutrients and metal balance for the anaerobic system [68].

\section{Materials and Methods}

\subsection{Biomass and Chemicals}

The diatom Phaeodactylum tricornutum (CIB-41 from CIBNOR (https: / / www.cibnor. gob.mx/, accessed on 22 November 2021) La Paz, Mexico) was obtained from the Mexican Company "Microalgas Oleas de México S.A." (Guadalajara, Mexico). The diatom was cultured in F/2 culture medium as reported previously by Guillard [69] and harvested at the end of the exponential phase. The microalga (diatom) was provided freeze-dried (freeze-dry system Labconco Freezone 18 L Benchtop Freeze Dry System, Kansas, MO, USA), packed in vacuum-sealed plastic bags and then was stored at $4 \pm 2{ }^{\circ} \mathrm{C}$ in the dark until use. All solutions used in this study were of analytical grade except for the standard solutions and chromatographic solvents. For supercritical fluid extraction, carbon 
dioxide and ethanol were purchased from Indura Air Products Group (Santiago, Chile) and Sigma-Aldrich (Santiago, Chile), respectively. Bovine Serum Albumin (BSA) (as the standard in protein analysis) and glucose (as the standard in carbohydrate determination) were acquired from Sigma-Aldrich (Santiago, Chile). For fucoxanthin identification and quantification, a standard of $>99 \%$ purity (Sigma-Aldrich, Santiago, Chile) was used. Ethyl acetate, acetonitrile, and ultrapure (MilliQ) water were of chromatographic grade (SigmaAldrich, Santiago, Chile) for high-performance liquid chromatography (HPLC).

\subsection{Determination of Particle Size Distribution of the P. tricornutum Freeze-Dried Biomass}

The particle size distribution of lyophilized diatom powder was determined using an electromagnetic sieve shaker (CISA Sieving Technologies, BA200N model, Barcelona, Spain). Eight sieves with ISO 3310-1 (ASTM E11) sizes of 10, 12, 16, 18, 35, 60, 120, and 230 were used. After 15 min shaking, the material retained in each sieve and the bottom pan was weighed. The mean particle diameter $(\mathrm{Dp})$ of the P. tricornutum powder was determined according to ASABE [70] using Equation (1).

$$
D_{P}=\exp \left\{\frac{\sum_{i=1}^{n}\left[\sqrt{W_{i} \cdot \log \left(d_{i} \cdot d_{i+1}\right)}\right]}{\sum_{i=1}^{n} W_{i}}\right\}
$$

where $D_{P}$ is the mean particle diameter $(m m) ; d_{i}$ is the diameter of the sieve opening $i$ $(\mathrm{mm}) ; d_{i+1}$ is the diameter of the sieve opening above sieve $\mathrm{i}(\mathrm{mm}) ; \mathrm{W}_{\mathrm{i}}$ is the retained mass (g); and $\mathrm{n}$ is the total number of fractions. The samples were kept in sealed plastic bags in a refrigerator till further analysis.

\subsection{SFE}

The SFE experiments were performed using a commercial SFE unit (Spe-ed SFE Helix, Applied Separations, Allentown, PA, USA), which was described in detail by Salinas et al. [71]. The aim of this experiment was to evaluate the effect of extraction conditions such as the temperature of $30^{\circ} \mathrm{C}$ and $50^{\circ} \mathrm{C}$; the pressure of 20,30 , and $40 \mathrm{MPa}$; and the concentration of ethanol as a co-solvent from $10 \%$ to $50 \% v / v$ on the extraction yield, fucoxanthin purity, and fucoxanthin recovery from the P. tricornutum biomass. Initially, different temperature and pressure conditions were evaluated using the freeze-dried biomass to optimize temperature and pressure parameters. For each extraction assay, $2.0 \mathrm{~g}$ of $P$. tricornutum biomass was packaged in a $24 \mathrm{~mL}$ extraction vessel (nominal volume), with the dimensions of 0.56 inch $(1.4224 \mathrm{~cm})$ of internal diameter and 5.9 inches $(14.986 \mathrm{~cm})$ of internal height (ASI Part Number 6414/7975; Applied Separations, Allentown, PA, USA), occupying a volume of $2.54 \mathrm{~mL}$, resulting in a bed density of $0.787 \mathrm{~g} / \mathrm{mL}$, which is approximately $10.6 \%$ of the total volume of the extraction vessel. The empty space of the extraction vessel was filled with $1.0 \mathrm{~mm}$ glass beads. The extraction vessel containing the biomass was assembled into the heated jacket at a selected temperature and kept for 15 min until the desired temperature was stabilized. $\mathrm{CO}_{2}$ was pumped until the desired pressure was reached, and the system was maintained for $10 \mathrm{~min}$ (static time) and the total time of extraction was set at $60 \mathrm{~min}$ according to a previous report on the extraction of carotenoids (xanthophyll) from microalgae [30]. The $\mathrm{CO}_{2}$ flow rate was measured using an electronic flow meter installed at the exit of the sample collection flask. After the static time, the outlet valve of the bed was opened, and the micrometric valve was adjusted to reach a $\mathrm{CO}_{2}$ flow rate of $2 \mathrm{~L} / \mathrm{min}$ that corresponds to a mass flow rate of $3.62 \mathrm{~g} / \mathrm{min}$. At this mass flow rate, superficial $\mathrm{CO}_{2}$ velocities $(\mathrm{U}: \mathrm{mm} / \mathrm{s})$ through the extraction vessel were calculated according to the temperature $\left(30^{\circ} \mathrm{C}\right.$ and $\left.50{ }^{\circ} \mathrm{C}\right)$ and pressure $(20,30$, and $40 \mathrm{MPa}$ ) of each treatment.

A factor that critically affects the cost of SFE processes for solid substrates is the extraction time [72], which in turn affects extraction yield that depends on substrate pretreatment, particle size $(\mathrm{Dp}), \mathrm{CO}_{2}$ temperature $(\mathrm{T})$, pressure $(\mathrm{P})$, and superficial velocity (U) [73]. This flow of $\mathrm{CO}_{2}$ during $60 \mathrm{~min}$ corresponds to a ratio of solvent to feed (S/F) 
of 108.6. The effect of operative conditions on the yield and extraction of fucoxanthin was expressed in terms of the total yield of extract and fucoxanthin purity and recovery from $P$. tricornutum, respectively. These variables were calculated using the following Equations (2)-(4):

$$
\begin{gathered}
\text { Total Yield }(\%)=(W e / W b) \times 100 \\
\text { Purity }(\mathrm{mg} / \mathrm{g})=W c / W e \\
\text { Recovery }(\%)=(W c / W t) \times 100
\end{gathered}
$$

where $W e$ is the weight of the extract $(\mathrm{g}), W b$ is the weight of biomass $(\mathrm{g})$; $W c$ is the weight of the fucoxanthin extracted (mg), and $W t$ is the reference weight of the fucoxanthin from conventional extraction (mg). This value was calculated on the basis of the initial content of fucoxanthin pigment in the diatom, expressed as $\mathrm{mg}$ of extract per gram of dry weight of P. tricornutum (equals to $9.82 \pm 0.70 \mathrm{mg} / \mathrm{g}$ ). Each experimental condition was replicated three to five times, and standard deviation (SD) was calculated for each value.

\subsection{Fucoxanthin Quantification by HPLC}

Fucoxanthin was extracted from $50 \mathrm{mg}$ of supercritical fluids extracts, and methanol $(0.05 \% w / v$ BHT) was added in all samples. The aliquots were filtered $(\varnothing=0.22 \mu \mathrm{m}$ filter $)$ and transferred into an amber vial for chromatographic analysis. Subsequently, fucoxanthin was separated and identified using the HPLC system, model 7100 (Merck Hitachi LaChrom, Tokyo, Japan) equipped with three pumps (flow rate of $1 \mathrm{~mL} / \mathrm{min}$ ), and a UV-Vis detector was used at $450 \mathrm{~nm}$. The samples $(20 \mu \mathrm{L})$ were injected into a capillary column $(\mathrm{C} 18$, $250 \mathrm{~mm} \times 4.6 \mathrm{~mm}, 5 \mu \mathrm{m}$, Restek, Bellefonte, PA, USA). The mobile phase consisted of solvent A (ethyl acetate) and solvent B (acetonitrile:water 90:10). The gradient procedure was $100 \%$ solvent B for $10 \mathrm{~min} ; 50 \%$ solvent B for $4 \mathrm{~min} ; 40 \%$ solvent B for $2 \mathrm{~min}$; and 100\% solvent B for $1 \mathrm{~min}$. Fucoxanthin was identified by comparing the retention times with that of the reference standard. Fresh standard solutions (1ppm to $20 \mathrm{ppm}$ of fucoxanthin) were prepared and injected to generate the standard fucoxanthin curve. The calculation of the free fucoxanthin concentration in the samples was performed using the standard curve that was found to be linear over the required range $\left(1-25 \mu \mathrm{g} / \mathrm{mL} ; R^{2}=0.9971\right)$. All analyses were performed in triplicate.

\subsection{Characterization of Biochemical Composition}

The characterization of biochemical composition was performed from the original biomass, the whole P. tricornutum, and the exhausted biomass. The exhausted biomass was a unique sample composed of a mixture resulting from the biomass pool after all SFE extractions studied. The protein content of P. tricornutum was analyzed colorimetrically using a microplate reader (Synergy HTX Multi-Mode microplate reader, software Gen5 2.0, BioTek Instruments, Winooski, VT, USA) and BSA solutions for the standard curve $(0.0-2.0 \mathrm{mg} / \mathrm{mL})$ by following the Lowry method [74]. The results are expressed as the percentage of total proteins with respect to their dry biomass $(\% w / w)$. Total carbohydrate content was determined according to the modified protocols of Dubois et al. [75] and Geresh et al. [76] using a series of glucose solutions as the standard $(0.0-1.0 \mathrm{mg} / \mathrm{mL})$. The biomass used for carbohydrate measurement was subjected to acid hydrolysis for cell rupture. Briefly, $20 \mathrm{mg}$ of the dry biomass was incubated in $5 \mathrm{~mL}$ of $2.5 \mathrm{M} \mathrm{HCl}$ for $3 \mathrm{~h}$ at $100{ }^{\circ} \mathrm{C}$ (Spectroquant Thermoreactor TR 320, Merck, Darmstadt, Germany). This mixture was neutralized with $5 \mathrm{~mL}$ of $2.5 \mathrm{M} \mathrm{NaOH}$ to obtain the microalgal extract. Finally, aliquots of $278 \mu \mathrm{L}$ of extract, $167 \mu \mathrm{L}$ of phenol solution $(5 \% w / v)$, and $1000 \mu \mathrm{L}$ of concentrated sulfuric acid were incubated for $30 \mathrm{~min}$ at room temperature, and the absorbance of these samples was measured at $483 \mathrm{~nm}$ using the microplate reader. The results are expressed as the percentage of total carbohydrates with respect to the dry biomass $(\% w / w)$. Total lipids were obtained according to the method of Axelsson et al. [77]. The dry biomass of P. tricornutum ( $20 \mathrm{mg}$ ) was resuspended in chloroform:methanol $(2: 1, v / v)$ by manually shaking the tube vigorously for a few seconds or until the biomass was dispersed in 
the solvent system. Finally, $0.73 \%(w / v) \mathrm{NaCl}$ water solution was added to produce a 2:1:0.8 system of chloroform:methanol:water $(v / v / v)$. The previous evaporation with $\mathrm{N}_{2}$ was performed using Flexivap Workstation (Glas-Col 109A YH-1, Terre Haute, IN, USA). Lipid content was expressed as the percentage of total lipids with respect to the biomass $(\% w / w)$. Proteins, total carbohydrates, and total lipids are expressed as the average of a triplicate $(n=3)$, and the data are expressed as mean \pm SD.

\subsection{Analytical Methods}

The parameters $\mathrm{pH}$, conductivity, total alkalinity (T-Alk), total solids, volatile solids (VS), mineral solids, total chemical oxygen demand (TCOD), soluble chemical oxygen demand, and volatile fatty acids (VFA) were determined according to the Standard Methods of the APHA et al. [78]. A Shimadzu model TOC-VCSH carbon analyzer was used for the determination of total organic carbon by the catalytic oxidation of total carbon present in the sample to $\mathrm{CO}_{2}$ and detection by infrared spectrophotometry. Metal content was determined by flame photometry [78] with a Perkin-Elmer A Analyst 300 atomic absorption spectrophotometer. The methodology proposed by the US Department of Agriculture and the US Composting Council [79] was used for the determination of ammoniacal nitrogen $\left(\mathrm{N}-\mathrm{NH}_{4}{ }^{+}\right)$, total Kjeldahl nitrogen (N-TKN), and phosphorus $\left(\mathrm{P}_{-} \mathrm{P}_{2} \mathrm{O}_{5}\right)$ content. Volatile fatty acids (VFA) such as acetic, propionic, butyric, isobutyric, valeric, and isovaleric acids were determined using a Hewlett-Packard HP-5890 gas chromatograph equipped with a $15 \mathrm{~m} \times 5.3 \times 10^{-4} \mathrm{~m}$ (i.d.) Nukol-silica semi-capillary column and a flame ionization detector.

\subsection{Anaerobic Inoculum and BMP}

Table 6 summarizes the main characteristics of the inoculum used for the biochemical methane potential (BMP) tests. The inoculum used was a baker's yeast vinasse obtained from La Golondrina plant, the municipal water company (EMACSA), Córdoba, Spain.

Table 6. Characteristics of the anaerobic inoculum used in the experiments.

\begin{tabular}{|c|c|c|c|}
\hline Variables & Value & Variables & Value \\
\hline $\mathrm{pH}$ & $7.70 \pm 0.01$ & TS (mg/L) & $17,565 \pm 115$ \\
\hline Conductivity $(\mathrm{mS} / \mathrm{cm})$ & $18.01 \pm 0.01$ & $\mathrm{MS}(\mathrm{mg} / \mathrm{L})$ & $11,855 \pm 110$ \\
\hline T-Alk $\left(\mathrm{mg} \mathrm{CO}{ }_{3} \mathrm{Ca} / \mathrm{L}\right)$ & $9496 \pm 65$ & VS (mg/L) & $5710 \pm 95$ \\
\hline VFA $(\mathrm{mg} \mathrm{C} / \mathrm{L})$ & $195 \pm 10$ & $\mathrm{~N}-\mathrm{NH} 4+(\mathrm{mg} / \mathrm{L})$ & $1055 \pm 6$ \\
\hline $\operatorname{VFA}\left(\mathrm{mg} \mathrm{CH} \mathrm{CH}_{3} \mathrm{COOH} / \mathrm{L}\right)$ & $485 \pm 25$ & N-TKN (mg/L) & $1579 \pm 10$ \\
\hline $\mathrm{PT}-\mathrm{P}_{2} \mathrm{O}_{5}(\mathrm{mg} / \mathrm{L})$ & $16.60 \pm 0.08$ & Acetic acid (mg/L) & $54.48 \pm 8.60$ \\
\hline $\mathrm{Cu}(\mathrm{mg} / \mathrm{L})$ & $0.310 \pm 0.002$ & Propionic acid (mg/L) & $8.64 \pm 2.35$ \\
\hline $\mathrm{Ni}(\mathrm{mg} / \mathrm{L})$ & $0.450 \pm 0.002$ & Isobutyric acid (mg/L) & $9.67 \pm 5.25$ \\
\hline $\mathrm{Zn}(\mathrm{mg} / \mathrm{L})$ & $2.750 \pm 0.030$ & Butyric acid (mg/L) & $19.40 \pm 5.40$ \\
\hline $\mathrm{Pb}(\mathrm{mg} / \mathrm{L})$ & $0.310 \pm 0.025$ & Isovaleric acid $(\mathrm{mg} / \mathrm{L})$ & n.d. \\
\hline $\mathrm{Cr}(\mathrm{mg} / \mathrm{L})$ & $0.078 \pm 0.002$ & Valeric acid (mg/L) & n.d. \\
\hline $\mathrm{Cd}(\mathrm{mg} / \mathrm{L})$ & $0.090 \pm 0.002$ & Caproic acid (mg/L) & n.d. \\
\hline
\end{tabular}

T-Alk: total alkalinity, VFA: volatile fatty acids, $\mathrm{P}_{\mathrm{T}}-\mathrm{P}_{2} \mathrm{O}_{5}$ : total phosphorous, TS: total solids, MS: mineral solids, VS: volatile solids, $\mathrm{N}^{-\mathrm{NH}_{4}}{ }^{+}$: ammoniacal nitrogen, N-TKN: total Kjeldahl Nitrogen and n.d.: no detected.

The AD of P. tricornutum was assessed by performing BMP assays in batches. The 1.2 $\mathrm{L}$ reactors or digesters were maintained at mesophilic temperature $\left(35 \pm 2{ }^{\circ} \mathrm{C}\right)$ using a thermostatic water bath (LAUDA RTM 20) and were continuously agitated at $200 \mathrm{rpm}$. An inoculum-to-substrate ratio was maintained at 4 (on a VS basis). A total of $5.7 \mathrm{~g}$ inoculum of VS was added in each reactor using an effective volume of $1000 \mathrm{~mL}$. The headspace of each flask was flushed with nitrogen to displace $\mathrm{O}_{2}$ and promote AD conditions. The $\mathrm{CH}_{4}$ produced was measured using a $1 \mathrm{~L}$ Boyle-Mariotte reservoir connected to each digester. $\mathrm{NaOH}$ solution $(6 \mathrm{~N})$ was used assuming that the non-captured gas from biogas was methane. The volume of $\mathrm{CH}_{4}$ was measured by water displacement. All methane volumes and yields were measured under standard temperature and pressure conditions (STP): $0{ }^{\circ} \mathrm{C}$ and $1 \mathrm{~atm}$. 
Before the experiments, the biomass was activated with GAL solution, a mixture of glucose $(50 \mathrm{~g} / \mathrm{L})$, lactic acid $(21 \mathrm{~mL} / \mathrm{L})$, and sodium acetate $(25 \mathrm{~g} / \mathrm{L})$ with a TCOD concentration of $86,900 \pm 75 \mathrm{mg} \mathrm{O} / \mathrm{L}$ and a $\mathrm{pH}$ of $7.05 \pm 0.01$. The experiments were performed in duplicate. Subsequently, the two digesters were fed with diatom P. tricornutum and the other two digesters with the extracted P. tricornutum (after the-SFE) to obtain $\mathrm{CH}_{4}$ yields from both substrates.

\subsection{Statistical Analysis}

The Statgraphics Centurion XVIII ${ }^{\circledR}$ Statistics software (StatPoint Technologies, Inc., Warrenton, VA, USA) was used for data elaboration and statistical analysis using a significance level of $95 \%$. One-way analysis of variance, together with Tukey's test, was used for group extracts based on statistically significant differences. The effect of each factor and its statistical significance for each response variable were analyzed. A p-value of $<0.05$ was considered statistically significant. All experiments were performed in triplicate $(n=3)$, and the data are expressed as the mean \pm SD.

\section{Conclusions}

In this study, we evaluated the use of P. tricornutum as biomass in the algae biorefinery concept using SFE, a green method, and biogas production to close the loop in a circular schedule. Fucoxanthin was the first valuable molecule to be recovered due to its many possible health benefits and high food market value. The best operating SFE parameters for the extraction yield, purity, and recovery of fucoxanthin from P. tricornutum by SFE were assessed. These optimal conditions were $30 \mathrm{MPa}$ pressure at $30{ }^{\circ} \mathrm{C}$ and $30 \% \mathrm{v} / \mathrm{v}$ ethanol for extraction yield and $30 \mathrm{MPa}$ pressure at $30^{\circ} \mathrm{C}$ and $40 \% v / v$ of the extractant for fucoxanthin purity and recovery. Fucoxanthin recovery improved by 3.5 times at $30 \mathrm{MPa}$ and $30{ }^{\circ} \mathrm{C}$ in the presence of ethanol, the most significant variable of SFE. Moreover, the diatom $P$. tricornutum was confirmed to be a potentially valuable natural resource for nutritional or nutraceutical purposes due to its good biochemical composition. The use of P. tricornutum and extracted diatom for AD enhanced the benefit of obtaining bioenergy in the form of biogas, obtaining methane yields of $77.15 \pm 3.85$ LSTP CH4/kg VS and $56.66 \pm 1.90$ LSTP $\mathrm{CH} 4 / \mathrm{kg}$ VS for the whole diatom and the extracted $P$. tricornutum, respectively, in addition to fucoxanthin extraction; thus, implying its use a circular economy strategy, minimizing the potential costs associated with SFE as a costly pretreatment process for biogas production.

Based on our findings, P. tricornutum can be a useful candidate to diversify its multipurpose use from biotechnological and bioactive applications to sustainable energy production, playing a key role in the "algae biorefinery" concept.

Author Contributions: Conceptualization, M.C.R.-D.; Data curation, B.R.; Formal analysis, M.C.R.D., B.R., M.Á.M. and M.C.G.; Funding acquisition, M.C.R.-D. and P.C.-M.; Investigation, F.S., E.M., M.Á.M. and M.C.G.; Methodology, M.C.R.-D., F.S., E.M. and M.Á.M.; Project administration, M.C.R.D. and P.C.-M.; Resources, M.C.R.-D.; Software, M.C.R.-D., B.R. and P.C.-M.; Validation, M.C.R.-D. and B.R.; Writing—original draft, M.C.R.-D. and B.R.; Writing—review and editing, B.R., M.Á.M., M.C.G. and P.C.-M. All authors have read and agreed to the published version of the manuscript.

Funding: This research was funded by the public funds of Chile-ANID (grants FONDECYT-11170017, and FONDEQUIP EQM-160073).

Institutional Review Board Statement: Not applicable.

Data Availability Statement: Not applicable.

Acknowledgments: The research group "LAMICBA" at University of Antofagasta, Chile, thanks "Microalgas Oleas de México S.A." for providing microalgal samples and to Inmaculada Bellido Padillo for her kind and excellent help with the experimental work.

Conflicts of Interest: The authors declare no conflict of interest. 


\section{References}

1. Lopez, P.J.; Desclés, J.; Allen, A.E.; Bowler, C. Prospects in diatom research. Curr. Opin. Biotechnol. 2005, 16, 180-186. [CrossRef] [PubMed]

2. Villanova, V.; Fortunato, A.E.; Singh, D.; Bo, D.D.; Conte, M.; Obata, T.; Jouhet, J.; Fernie, A.R.; Marechal, E.; Falciatore, A. Investigating mixotrophic metabolism in the model diatom Phaeodactylum tricornutum. Philos. Trans. R. Soc. B-Biol. Sci. 2017, 372, 20160404. [CrossRef] [PubMed]

3. Field, C.B.; Behrenfeld, M.J.; Randerson, J.T.; Falkowski, P. Primary production of the biosphere: Integrating terrestrial and oceanic components. Science 1998, 281, 237-240. [CrossRef] [PubMed]

4. Armbrust, E.V. The life of diatoms in the world's oceans. Nature 2009, 459, 185-192. [CrossRef]

5. Dolch, L.-J.; Maréchal, E. Inventory of Fatty Acid Desaturases in the Pennate Diatom Phaeodactylum tricornutum. Mar. Drugs 2015, 13, 1317-1339. [CrossRef]

6. Lebeau, T.; Robert, J.-M. Diatom cultivation and biotechnologically relevant products. Part II: Current and putative products. Appl. Microbiol. Biotechnol. 2003, 60, 624-632. [CrossRef]

7. Kuppusamy, P.; Soundharrajan, I.; Srigopalram, S.; Yusoff, M.M.; Maniam, G.P.; Govindan, N.; Choi, K.C. Potential pharmaceutical and biomedical applications of Diatoms microalgae-An overview. Indian J. Geo Mar. Sci. 2017, 46, 663-667.

8. Sharma, N.; Simon, D.P.; Diaz-Garza, A.M.; Fantino, E.; Messaabi, A.; Meddeb-Mouelhi, F.; Germain, H.; Desgagné-Penix, I. Diatoms Biotechnology: Various Industrial Applications for a Greener Tomorrow. Front. Mar. Sci. 2021, 8. [CrossRef]

9. Atalah, E.; Cruz, C.M.H.; Izquierdo, M.S.; Rosenlund, G.; Caballero, M.J.; Valencia, A.; Robaina, L. Two microalgae Crypthecodinium cohnii and Phaeodactylum tricornutum as alternative source of essential fatty acids in starter feeds for seabream (Sparus aurata). Aquaculture 2007, 270, 178-185. [CrossRef]

10. Kim, S.M.; Jung, Y.-J.; Kwon, O.-N.; Cha, K.H.; Um, B.-H.; Chung, D.; Pan, C.-H. A potential commercial source of fucoxanthin extracted from the microalga Phaeodactylum tricornutum. Appl. Biochem. Biotechnol. 2012, 166, 1843-1855. [CrossRef]

11. Eilers, U.; Bikoulis, A.; Breitenbach, J.; Büchel, C.; Sandmann, G. Limitations in the biosynthesis of fucoxanthin as targets for genetic engineering in Phaeodactylum tricornutum. J. Appl. Phycol. 2016, 28, 123-129. [CrossRef]

12. Miyashita, K.; Nishikawa, S.; Beppu, F.; Tsukui, T.; Abe, M.; Hosokawa, M. The allenic carotenoid fucoxanthin, a novel marine nutraceutical from brown seaweeds. J. Sci. Food Agric. 2011, 91, 1166-1174. [CrossRef] [PubMed]

13. Maeda, H.; Hosokawa, M.; Sashima, T.; Funayama, K.; Miyashita, K. Fucoxanthin from edible seaweed, Undaria pinnatifida, shows antiobesity effect through UCP1 expression in white adipose tissues. Biochem. Biophys. Res. Commun. 2005, 332, 392-397. [CrossRef] [PubMed]

14. Sachindra, N.M.; Sato, E.; Maeda, H.; Hosokawa, M.; Niwano, Y.; Kohno, M.; Miyashita, K. Radical scavenging and singlet oxygen quenching activity of marine carotenoid fucoxanthin and its metabolites. J. Agric. Food Chem. 2007, 55, 8516-8522. [CrossRef] [PubMed]

15. Guo, B.; Liu, B.; Yang, B.; Sun, P.; Lu, X.; Liu, J.; Chen, F. Screening of diatom strains and characterization of Cyclotella cryptica as a potential fucoxanthin producer. Mar. Drugs 2016, 14, 125. [CrossRef]

16. Poojary, M.M.; Barba, F.J.; Aliakbarian, B.; Donsì, F.; Pataro, G.; Dias, D.A.; Juliano, P. Innovative alternative technologies to extract carotenoids from microalgae and seaweeds. Mar. Drugs 2016, 14, 214. [CrossRef]

17. Chemat, F.; Vian, M.A.; Cravotto, G. Green extraction of natural products: Concept and principles. Int. J. Mol. Sci. 2012, 13, 8615-8627. [CrossRef]

18. Armenta, S.; Garrigues, S.; Esteve-Turrillas, F.A.; de la Guardia, M. Green extraction techniques in green analytical chemistry. Trac-Trends Anal. Chem. 2019, 116, 248-253. [CrossRef]

19. da Silva, R.P.F.F.; Rocha-Santos, T.A.P.; Duarte, A.C. Supercritical fluid extraction of bioactive compounds. Trac-Trends Anal. Chem. 2016, 76, 40-51. [CrossRef]

20. Suganya, T.; Varman, M.; Masjuki, H.; Renganathan, S. Macroalgae and microalgae as a potential source for commercial applications along with biofuels production: A biorefinery approach. Renew. Sust. Energ. Rev. 2016, 55, 909-941. [CrossRef]

21. Cherubini, F. The biorefinery concept: Using biomass instead of oil for producing energy and chemicals. Energy Conv. Manag. 2010, 51, 1412-1421. [CrossRef]

22. Roadmap, U. Roadmap for Biomass Technologies in the United States. Biomass Research and Development Technical Advisory Committee. 2002. Available online: https:// biomassboard.gov/sites/default/files/pdfs/final_biomass_roadmap_2002kw.pdf (accessed on 11 November 2021).

23. Naik, S.N.; Goud, V.V.; Rout, P.K.; Dalai, A.K. Production of first and second generation biofuels: A comprehensive review. Renew. Sust. Energ. Rev. 2010, 14, 578-597. [CrossRef]

24. Gujer, W.; Zehnder, A.J.B. Conversion Processes in Anaerobic Digestion. Water Sci. Technol. 1983, 15, 127-167. [CrossRef]

25. Passos, F.; Uggetti, E.; Carrère, H.; Ferrer, I. Pretreatment of microalgae to improve biogas production: A review. Bioresour. Technol. 2014, 172, 403-412. [CrossRef] [PubMed]

26. Zhao, B.; Ma, J.; Zhao, Q.; Laurens, L.; Jarvis, E.; Chen, S.; Frear, C. Efficient anaerobic digestion of whole microalgae and lipid-extracted microalgae residues for methane energy production. Bioresour. Technol. 2014, 161, 423-430. [CrossRef]

27. Lage, S.; Willfors, A.; Hörnberg, A.; Gentili, F. Impact of organic solvents on lipid-extracted microalgae residues and wastewater sludge co-digestion. Bioresour. Technol. Reports 2021, 16, 100850. [CrossRef] 
28. Sardessai, Y.N.; Bhosle, S. Industrial potential of organic solvent tolerant bacteria. Biotechnology Progress 2004, 20 , 655-660. [CrossRef]

29. Cord-Ruwisch, R. Thermodynamics of anaerobic digestion: Mechanism of suppression on biogas production during acidogenesis. INMATEH-Agric. Eng. 2019, 57, 287-301.

30. Ruiz-Domínguez, M.C.; Marticorena, P.; Sepúlveda, C.; Salinas, F.; Cerezal, P.; Riquelme, C. Effect of Drying Methods on Lutein Content and Recovery by Supercritical Extraction from the Microalga Muriellopsis sp. (MCH35) Cultivated in the Arid North of Chile. Mar. Drugs 2020, 18, 528. [CrossRef]

31. Del Valle, J.M.; Uquiche, E.L. Particle size effects on supercritical $\mathrm{CO}_{2}$ extraction of oil-containing seeds. J. Am. Oil Chem. Soc. 2002, 79, 1261-1266. [CrossRef]

32. Snyder, J.; Friedrich, J.; Christianson, D. Effect of moisture and particle size on the extractability of oils from seeds with supercritical CO2. J. Am. Oil Chem. Soc. 1984, 61, 1851-1856. [CrossRef]

33. Reverchon, E.; Marrone, C. Modeling and simulation of the supercritical CO2 extraction of vegetable oils. J. Supercrit. Fluids 2001, 19, 161-175. [CrossRef]

34. Crampon, C.; Boutin, O.; Badens, E. Supercritical carbon dioxide extraction of molecules of interest from microalgae and seaweeds. Ind. Eng. Chem. Res. 2011, 50, 8941-8953. [CrossRef]

35. Brunner, G. Gas Extraction: An Introduction to Fundamentals of Supercritical Fluids and the Application to Separation Processes; Springer Science \& Business Media: Berlin, Germany, 2013; Volume 4.

36. Vieira de Melo, S.; Costa, G.M.; Viana, A.C.; Pessoa, F.L. Computation of crossover pressure for synthesis of supercritical fluid separation systems. Comput. Chem. Eng. 2009, 27, 399-404.

37. Vieira de Melo, S.; Costa, G.M.N.; Viana, A.; Pessoa, F. Solid pure component property effects on modeling upper crossover pressure for supercritical fluid process synthesis: A case study for the separation of Annatto pigments using SC-CO 2 . J. Supercrit. Fluids 2009, 49, 1-8. [CrossRef]

38. Rad, H.B.; Sabet, J.K.; Varaminian, F. Study of solubility in supercritical fluids: Thermodynamic concepts and measurement methods-a review. Braz. J. Chem. Eng. 2020, 36, 1367-1392. [CrossRef]

39. Foster, N.R.; Gurdial, G.S.; Yun, J.S.; Liong, K.K.; Tilly, K.D.; Ting, S.S.; Singh, H.; Lee, J.H. Significance of the crossover pressure in solid-supercritical fluid phase equilibria. Ind. Eng. Chem. Res. 1991, 30, 1955-1964. [CrossRef]

40. Fabrowska, J.; Ibañez, E.; Łęska, B.; Herrero, M. Supercritical fluid extraction as a tool to valorize underexploited freshwater green algae. Algal Res. 2016, 19, 237-245. [CrossRef]

41. Ruiz-Domínguez, M.C.; Cerezal, P.; Salinas, F.; Medina, E.; Renato-Castro, G. Application of Box-Behnken Design and Desirability Function for Green Prospection of Bioactive Compounds from Isochrysis galbana. Appl. Sci.-Basel 2020, 10, 2789. [CrossRef]

42. Roh, M.K.; Uddin, M.S.; Chun, B.S. Extraction of Fucoxanthin and Polyphenol from Undaria pinnatifida Using Supercritical Carbon dioxide with Co-solvent. Biotechnol. Bioprocess Eng. 2008, 13, 724-729. [CrossRef]

43. Shi, J.; Mittal, G.; Kim, E.; Xue, S.J. Solubility of Carotenoids in Supercritical CO2. Food Rev. Int. 2007, 23, 341-371. [CrossRef]

44. Kim, S.M.; Kang, S.-W.; Kwon, O.-N.; Chung, D.; Pan, C.-H. Fucoxanthin as a major carotenoid in Isochrysis aff. galbana: Characterization of extraction for commercial application. J. Korean Soc. Appl. Biol. Chem. 2012, 55, 477-483. [CrossRef]

45. Zhang, W.; Wang, F.; Gao, B.; Huang, L.; Zhang, C. An integrated biorefinery process: Stepwise extraction of fucoxanthin, eicosapentaenoic acid and chrysolaminarin from the same Phaeodactylum tricornutum biomass. Algal Res. 2018, 32, 193-200. [CrossRef]

46. Herrero, M.; Cifuentes, A.; Ibañez, E. Sub-and supercritical fluid extraction of functional ingredients from different natural sources: Plants, food-by-products, algae and microalgae: A review. Food Chem. 2006, 98, 136-148. [CrossRef]

47. Gómez-Loredo, A.; Benavides, J.; Rito-Palomares, M. Partition behavior of fucoxanthin in ethanol-potassium phosphate two-phase systems. J. Chem. Technol. Biotechnol. 2014, 89, 1637-1645. [CrossRef]

48. Conde, E.; Moure, A.; Domínguez, H. Supercritical CO2 extraction of fatty acids, phenolics and fucoxanthin from freeze-dried Sargassum muticum. J. Appl. Phycol. 2015, 27, 957-964. [CrossRef]

49. Gilbert-López, B.; Barranco, A.; Herrero, M.; Cifuentes, A.; Ibáñez, E. Development of new green processes for the recovery of bioactives from Phaeodactylum tricornutum. Food Res. Int. 2017, 99, 1056-1065. [CrossRef]

50. Mussgnug, J.H.; Klassen, V.; Schlüter, A.; Kruse, O. Microalgae as substrates for fermentative biogas production in a combined biorefinery concept. J. Biotechnol. 2010, 150, 51-56. [CrossRef]

51. Sialve, B.; Bernet, N.; Bernard, O. Anaerobic digestion of microalgae as a necessary step to make microalgal biodiesel sustainable. Biotechnol. Adv. 2009, 27, 409-416. [CrossRef]

52. Zabed, H.M.; Akter, S.; Yun, J.; Zhang, G.; Zhang, Y.; Qi, X. Biogas from microalgae: Technologies, challenges and opportunities. Renew. Sust. Energ. Rev. 2020, 117, 109503. [CrossRef]

53. Di Lena, G.; Casini, I.; Lucarini, M.; del Pulgar, J.S.; Aguzzi, A.; Caproni, R.; Gabrielli, P.; Lombardi-Boccia, G. Chemical characterization and nutritional evaluation of microalgal biomass from large-scale production: A comparative study of five species. Eur. Food Res. Technol. 2020, 246, 323-332. [CrossRef]

54. Bernaerts, T.M.M.; Gheysen, L.; Kyomugasho, C.; Jamsazzadeh Kermani, Z.; Vandionant, S.; Foubert, I.; Hendrickx, M.E.; Van Loey, A.M. Comparison of microalgal biomasses as functional food ingredients: Focus on the composition of cell wall related polysaccharides. Algal Res. 2018, 32, 150-161. [CrossRef] 
55. Wu, H.; Li, T.; Wang, G.; Dai, S.; He, H.; Xiang, W. A comparative analysis of fatty acid composition and fucoxanthin content in six Phaeodactylum tricornutum strains from diff erent origins. Chin. J. Oceanol. Limnol. 2016, 34, 391-398. [CrossRef]

56. Matos, Â.P.; Feller, R.; Moecke, E.H.S.; de Oliveira, J.V.; Junior, A.F.; Derner, R.B.; Sant'Anna, E.S. Chemical Characterization of Six Microalgae with Potential Utility for Food Application. J. Am. Oil Chem. Soc. 2016, 93, 963-972. [CrossRef]

57. Niccolai, A.; Chini Zittelli, G.; Rodolfi, L.; Biondi, N.; Tredici, M.R. Microalgae of interest as food source: Biochemical composition and digestibility. Algal Res. 2019, 42, 101617. [CrossRef]

58. Rincón, B. Chapter 12-Biogas from microalgae. In Handbook of Microalgae-Based Processes and Products; Jacob-Lopes, E., Maroneze, M.M., Queiroz, M.I., Zepka, L.Q., Eds.; Academic Press: London, UK, 2020; Volume 1, pp. 311-328. [CrossRef]

59. Ramos-Suárez, J.L.; Carreras, N. Use of microalgae residues for biogas production. Chem. Eng. J. 2014, 242, 86-95. [CrossRef]

60. Caporgno, M.P.; Olkiewicz, M.; Torras, C.; Salvadó, J.; Clavero, E.; Bengoa, C. Effect of pre-treatments on the production of biofuels from Phaeodactylum tricornutum. J. Environ. Manag. 2016, 177, 240-246. [CrossRef] [PubMed]

61. Frigon, J.-C.; Abdou, R.H.; McGinn, P.J.; O'Leary, S.J.; Guiot, S.R. Fate of palmitic, palmitoleic and eicosapentaenoic acids during anaerobic digestion of Phaeodactylum tricornutum at varying lipid concentration. Algal Res. 2014, 6, 46-51. [CrossRef]

62. Zamalloa, C.; Boon, N.; Verstraete, W. Anaerobic digestibility of Scenedesmus obliquus and Phaeodactylum tricornutum under mesophilic and thermophilic conditions. Appl. Energy 2012, 92, 733-738. [CrossRef]

63. Rittmann, B.E.; McCarty, P.L. Biotecnología del Medio Ambiente, Principios y Aplicaciones; McGraw Hill: Madrid, Spain, 2001; 760 p, ISBN 9788448132804.

64. Zhang, J.; Wang, S.; Lang, S.; Xian, P.; Xie, T. Kinetics of combined thermal pretreatment and anaerobic digestion of waste activated sludge from sugar and pulp industry. Chem. Eng. J. 2016, 295, 131-138. [CrossRef]

65. Chen, Y.; Cheng, J.J.; Creamer, K.S. Inhibition of anaerobic digestion process: A review. Bioresour. Technol. 2008, 99, 4044-4064. [CrossRef] [PubMed]

66. Angelidaki, I.; Ahring, B. Thermophilic anaerobic digestion of livestock waste: The effect of ammonia. Appl. Microbiol. Biotechnol. 1993, 38, 560-564. [CrossRef]

67. Hejnfelt, A.; Angelidaki, I. Anaerobic digestion of slaughterhouse by-products. Biomass Bioenerg. 2009, 33, 1046-1054. [CrossRef]

68. Chong, C.C.; Cheng, Y.W.; Ishak, S.; Lam, M.K.; Lim, J.W.; Tan, I.S.; Show, P.L.; Lee, K.T. Anaerobic digestate as a low-cost nutrient source for sustainable microalgae cultivation: A way forward through waste valorization approach. Sci. Total Environ. 2022, 803, 150070. [CrossRef] [PubMed]

69. Guillard, R.R. Culture of phytoplankton for feeding marine invertebrates. In Culture of Marine Invertebrate Animals; Springer: New York, NY, USA, 1975; pp. 29-60.

70. American Society of Agricultural and Biological Engineers. Method of Determining and Expressing Particle Size of Chopped Forage Materials by Screening; ASABE: St. Joseph, MI, USA, 2007; Volume 424, pp. 663-665.

71. Salinas, F.; Vardanega, R.; Espinosa-Álvarez, C.; Jimenéz, D.; Muñoz, W.B.; Ruiz-Domínguez, M.C.; Meireles, M.A.A.; CerezalMezquita, P. Supercritical fluid extraction of chañar (Geoffroea decorticans) almond oil: Global yield, kinetics and oil characterization. J. Supercrit. Fluids 2020, 104824. [CrossRef]

72. Rosa, P.T.; Meireles, M.A.A. Rapid estimation of the manufacturing cost of extracts obtained by supercritical fluid extraction. $J$ Food Eng. 2005, 67, 235-240. [CrossRef]

73. del Valle, J.M.; Núñez, G.A.; Aravena, R.I. Supercritical CO2 oilseed extraction in multi-vessel plants. 1. Minimization of operational cost. J. Supercrit. Fluids 2014, 92, 197-207. [CrossRef]

74. Lowry, O.H.; Rosebrough, N.J.; Farr, A.L.; Randall, R.J. Protein measurement with the Folin phenol reagent. J. Biol. Chem. 1951, 193, 265-275. [CrossRef]

75. Dubois, M.; Gilles, K.A.; Hamilton, J.K.; Rebers, P.t.; Smith, F. Colorimetric method for determination of sugars and related substances. Anal. Chem. 1956, 28, 350-356. [CrossRef]

76. Geresh, S.; Adin, I.; Yarmolinsky, E.; Karpasas, M. Characterization of the extracellular polysaccharide of Porphyridium sp.: Molecular weight determination and rheological properties. Carbohydr. Polym. 2002, 50, 183-189. [CrossRef]

77. Axelsson, M.; Gentili, F. A Single-Step Method for Rapid Extraction of Total Lipids from Green Microalgae. PLoS ONE 2014, 9, 6. [CrossRef] [PubMed]

78. APHA; AWWA; WPCF. Standard Methods for the Examination of Water and Wastewater, 17th ed.; Clesceri, L.S., Greenberg, A.E., Eaton, A.D., Rice, E.W., Franson, M.A.H., Eds.; American Public Health Association: Washington, DC, USA, 2005.

79. The US Department of Agriculture and the US Composting Council. Test Methods for the Examination of Composting and Compost (TMECC); Edaphos International: Houston, TX, USA, 2002. Available online: https://www.compostingcouncil.org/page/tmecc (accessed on 22 November 2021). 